\title{
New mantises (Insecta: Mantodea) in Cretaceous ambers from Lebanon, Spain, and Myanmar
}

Xavier Delclòs ${ }^{\mathrm{a}, *}$, Enrique Peñalver ${ }^{\mathrm{b}}$, Antonio Arillo ${ }^{\mathrm{c}}$, Michael S. Engel ${ }^{\mathrm{d}}$, André $\mathrm{Nel}^{\mathrm{e}}$, Dany Azar ${ }^{\mathrm{f}, \mathrm{g}}$, Andrew Ross ${ }^{\mathrm{h}}$

${ }^{\text {a }}$ Departament d'Estratigrafia, Paleontologia i Geociències Marines, and Institut de Recerca de la Biodiversitat (IRBio), Facultat de Geologia, Universitat de Barcelona, Martí i Franquès s/n, 08028 Barcelona, Spain

${ }^{\mathrm{b}}$ Museo Geominero, Instituto Geológico y Minero de España, Ríos Rosas 23, 28003 Madrid, Spain

${ }^{c}$ Departamento de Zoología y Antropología Física, Facultad de Biología, Universidad Complutense, 28040 Madrid, Spain

${ }^{\mathrm{d} D i v i s i o n}$ of Entomology (Paleoentomology), Natural History Museum, and Department of Ecology \& Evolutionary Biology, 1501 Crestline Drive - Suite 140, University of Kansas, Lawrence, Kansas 66045, USA

${ }^{e}$ Institut de Systématique, Évolution, Biodiversité, ISYEB - UMR 7205 - CNRS, MNHN, UPMC, EPHE, Muséum national d'Histoire naturelle, Sorbonne Universités, 57 rue Cuvier, CP 50, Entomologie, 75005 Paris, France

${ }^{\mathrm{f}}$ Lebanese University, Faculty of Sciences II, Department of Natural Sciences, Fanar, Matn P.O. Box 26110217, Lebanon

${ }^{\mathrm{g}}$ Nanjing Institute of Geology and Palaeontology, Chinese Academy of Sciences, Nanjing 210008, People's Republic of China

${ }^{\mathrm{h}}$ Department of Natural Sciences, National Museums Scotland, Chambers St., Edinmburgh, EH1 1JF, UK

*Corresponding author. Tel. +34934021381

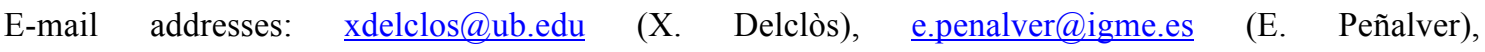

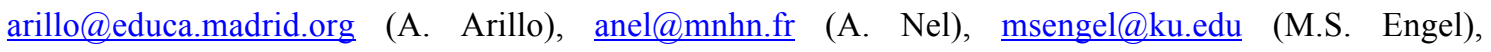
azar@mnhn.fr (D. Azar), A.Ross@nms.ac.uk (A. Ross). 


\section{ABSTRACT}

Diverse new material of mantises found in the Cretaceous amber-bearing deposits from Lebanon (Barremian), Spain (Albian), and Myanmar (Albian-Cenomanian) are described and figured. The Lebanese and Spanish forms are nymphs; while the one from Myanmar is an adult specimen. The Lebanese nymph corresponds to a new specimen of Burmantis lebanensis Grimaldi, 2003 while the adult Burmese (Myanmar) specimen belongs to the new species Burmantis zherikhini. The Spanish specimen represents a new genus and species and is established as Aragonimantis aenigma, but is considered family incertae sedis. The Spanish specimen is the first record of Mesozoic mantises from western-European amber deposits. A revised phylogenetic hypothesis for Cretaceous mantises is proposed.

Keywords: Amber; Mantodea; New species; Phylogeny; Cretaceous

\section{Introduction}

Mantodea (mantises) are a lineage of polyneopteran insects, comprising approximately 2,400 described species distributed in nearly 434 genera (Ehrmann, 2002; Svenson and Whiting, 2004; Wieland, 2013), and are among the more familiar of insect groups owing to their characteristic raptorial forelegs, large eyes, and distinctive stance and habitus (Zherikhin, 2002; Grimaldi and Engel, 2005). Mantises are predatory and occupy a wide distribution across generally warmer biomes, mainly in intertropical 
regions, and having diversified into a considerable variety of habitats from African deserts to Asian rainforests.

The monophyly of Mantodea is well supported by several characters such as the presence of raptorial forelegs, presence of an ultrasound "ear" on the metathorax (not present in Cretaceous mantises), and a femoral brush, among others traits (Roy, 1999; Svenson and Withing, 2004; Grimaldi and Engel, 2005). Mantodea is phylogenetically related to the clade of crown-group Blattaria and Isoptera in the more inclusive Dictyoptera (Kevan, 1977; Lo et al., 2000; Grimaldi and Engel, 2005), which evolved from roach-like insects with reduced ovipositors. The oldest known definitive representatives of the Mantodea date from the Late Jurassic and Early Cretaceous (Grimaldi, 1997; Zherikhin, 2002; Lo et al., 2003), although some Late Carboniferous and Permian taxa have been argued to represent stem-group Mantodea (e.g., Béthoux and Wieland, 2009; Béthoux et al., 2010). Among the roaches, Vršanský (2005) proposed that Mantodea evolved from the Jurassic, free-living family Liberiblattinidae Vršanský, 2002a, and as a result of a shift to a predaceous mode of life, a hypothesis that implies that the family is paraphyletic and of no classificatory value (see further comments regarding this hypothesis in Béthoux and Wieland, 2009). Kukalová-Peck and Beutel (2012) and Gorochov (2013) denied the hypothesis proposed by Béthoux and Wieland (2009) and Béthoux et al. (2010) regarding the relationship between Mantodea and the Paleozoic Strephocladidae Martynov, 1938 (a junior synonym of the family Anthracoptilidae Handlirsch, 1922; after Guan et al. 2015), a Paleozoic group that similarly possesses raptorial forelegs (see Béthoux and Wieland, 2009). KukalováPeck and Beutel (2012) considered this family as stem-Holometabola while Gorochov (2013) proposed a relationship with the Eoblattida (= Cnemidolestodea sensu Béthoux, 2005). The hypothesis put forward by Béthoux and co-workers was based on wing- 
venational organization of some "protorthopteran" species, and regards that some of these Carboniferous and Permian species belonged to stem-group Mantodea, distant relatives of modern mantises, and at an age of about 175 My earlier than previous evidence suggested for the clade. Recently, Guan et al. (2015) proposed that the Anthracoptilidae belong to the clade Paoliida (sensu Prokop et al., 2014), themselves a sister group to or stem group of the Dictyoptera, and this seems to be the best supported conclusion based on available evidence, and considered Strephocladidae a junior synonimy of Anthracoptilidae. Vršanský (2012) erected the family Mutoviidae for species from the Permian of Russia and which he regarded as Blattaria; however, members of this family show a clear division of veins R1 and Rs, and which is more typical of Mantodea than of Blattaria. Accordingly, this family should be regarded as of uncertain placement within the Dictyoptera until more complete material is discovered, particularly the structure of the forelegs.

Vršanský and Bechly (2015) recently erected the family Manipulatoridae for one interesting new species, Manipulator modificaputis, from Burmese amber. They regarded it as 'an early side branch of the stem group of Mantodea' though reject it from Mantodea due to the absence of a forewing pseudovein and median ocellus, undifferentiated mouthparts, cockroach-like hind wing venation, and only partly differentiated forelegs. They puzzlingly dubbed it a 'cockroach', which they go on to use for all crown Dictyoptera. Firstly, we reject the use of the term 'cockroach' in this way as it causes confusion and differs utterly from almost universal usage, and prefer the more traditional application of this common name for all crown-group Blattaria excluding Isoptera (termites), and prefer to use 'roachoids' for all other cockroach-like Dictyoptera. They placed it within Blattaria based on the form of the hind-wing venation, which although cockroach-like is not that dissimilar from the two early mantis 
hind wings described by Gratshev and Zherikhin (1993), and which also have a branching R. It should be expected that the hind wings of early mantises and contemporary cockroaches would not be very different so this reason alone is insufficient to place M. modificaputis in Blattaria. Secondly, it is described as a 'pursuit predator' given the absence of spines on its walking legs. Certainly it could have been predatory owing to the mantis-like shape of the head, with large, exophthalmic compound eyes and apparently raptorial forelegs, though it does not appear to have specialist spines for prey capture. Its ability as an 'active runner and pursuit predator' is highly dubious as mantises also do not have spines on their mid- and hind-legs yet hunt by stealth rather than active pursuit. We prefer to regard $M$. modificaputis as a mantislike dictyopteran, and one that was more likely a stealth predator.

Generally, a Jurassic/Cretaceous age has been argued for crown-group Mantodea (e.g., Zherikhin, 2002; Grimaldi, 2003; Grimaldi and Engel, 2005; Vršanský, 2002a, 2002b; Lo et al., 2003, among others). Model-based estimates based strictly on molecular data have even hypothesized an Early Jurassic age, and with modern Mantodea originating on Gondwanaland during the Early Cretaceous (Svenson and Whiting, 2009). The first major divergence among the lineage putatively occurring as a result of the Atlantic breackup, separating Africa from South America. According to Svenson and Whiting (2007) the breakup of Gondwanaland produced numerous divergences within the order, although understandably the degree to which this accords with the fossil record is unknown given the scant direct evidence of mantis diversity during the Mesozoic. A recent molecular phylogenetic analysis of the entire Dictyoptera proposed a putative age of Late Carboniferous - Early Permian for the stemmantodeans, a range interestingly in line with those ages argued by some authors although their specific taxa were likely not stem-Mantodea (e.g., Béthoux and Wieland, 
2009; Béthoux et al., 2010), and a Jurassic diversification for crown-group mantodeans (Legendre et al., 2015).

Over the last two decades, diverse phylogenetic hypotheses have been proposed for Dictyoptera, based on morphological and molecular sources of data as well as a growing appreciation and incorporation of fossil evidence. Not surprisingly, with the growth of data and methods of analysis, diverse and not necessarily mutually reconcilably results have been obtained, although some significant advances have been made. Some of these studies recovered Mantodea with Blattaria and these as sister to the Isoptera (e.g., Thorne and Carpenter, 1992; Kambhampati, 1995), or Mantodea with Isoptera collectively as the sister of Blattaria (DeSalle, 1994), Mantodea as sister to Blattidae and Isoptera (e.g., Klass, 1997, 2000; Lo et al., 2000, 2003; Deitz et al., 2003; Pellens et al., 2007; Misof et al., 2014; Legendre et al., 2015), and/or with Isoptera nested among Blattaria, thereby resurrecting a $19^{\text {th }}$ and early $20^{\text {th }}$ concept for the affinity of termites (e.g., Inward et al., 2007; Grimaldi and Engel, 2005; Engel et al., 2009; Ware et al., 2010; Krishna et al., 2013).

The first formal quantitative analysis of extant mantodean phylogeny was provided by Svenson and Whiting (2004), who considered Blattaria as sister to Mantodea and with Isoptera subordinate in the former. Their data supported the notion that previous phylogenetic estimates and classifications included a large number of paraphyletic families and subfamilies (i.e., Roy, 1999; Ehrmann, 2002). Presently, relationships among the various constituent lineages, as well as definitive evidence for monophyly of those groups, remain unclear. Beier (1968) split Mantodea into eight living families: Chaeteessidae, Mantoididae, Metallyticidae, Amorphoscelididae, Eremiaphilidae, Empusidae, Hymenopodidae, and Mantidae, considering the first three as the most basal and with most species clustered in Mantidae. The current classification recognizes more 
than 18 families (Ehrmann, 2002), but as mentioned above it seems clear that several are paraphyletic as currently circumscribed (Svenson and Whiting, 2004, 2009). For Recent mantises it is generally well supported that the family Mantoididae is sister to all other crown-group Mantodea (Klass, 1997; Svenson and Whiting, 2004). Nonetheless, Wieland (2010) proposed that the basal dichotomies within Mantodea were $[$ Chaeteessa $]+([$ Metallyticus $]+[$ Mantoida + remaining Mantodea $])$. The first serious analysis that integrated fossil species was that of Grimaldi (2003) who recovered the earliest Cretaceous genus Baissomantis (Baissomantidae) as sister to the true mantises (order Mantodea), and that the majority of Cretaceous species formed a basal grade to all extant clades. Grimaldi (2003) also considered Ambermantis (Ambermantidae) and all living mantises which have a profemur with discoidal spines (Eumantodea) to comprise the clade Neomantodea, with Chaeteessa as the sister group to all other Eumantodea. The analysis of Grimaldi (2003) further indicated that mantises were basal to living roaches and termites owing to the presence of various plesiomorphies relative to the latter.

Mantis fossils are comparatively rare (Ehrmann, 1999, 2002; Grimaldi and Engel, 2005; Wieland, 2013), and this has hampered considerably our understanding of the historical evolution of the group (Table 1). Given that fossils have the potential to radically recast our notions of relationships, biogeographic patterns, and the origins of evolutionary novelties and biological phenomena; this is a lamentable state of affairs. Although several mantodean specimens have been found from amber-bearing deposits throughout the world (Ehrmann, 2002), up to the present only 29 fossil species have been described (Table 1). Remarkably, from among this total 21 have been found in Cretaceous deposits, both in limestones (mainly wings) and amber (some complete adults but mainly unwinged nymphs) (Gratshev and Zherikhin, 1993; Grimaldi, 2003; 
Hörnig et al., 2013). Further specimens from the Lower Cretaceous amber of Japan (http://news.nationalgeographic.com/news/2008/04/080425-amber-mantis.html), Upper Cretaceous of Canada (Pike, 1995), and the Lower Cretaceous limestones of Spain and Mongolia (Vršanský, 2002a, 2005), etc., remain unstudied and without formal description. Grimaldi (2003) considered that the Mesozoic genera Amorphoscelites Gratshev and Zherikhin, 1993, Burmantis Grimaldi, 2003, Chaeteessites Gratshev and Zherikhin, 1993, Cretophotina Gratshev and Zherikhin, 1993, Electromantis Gratshev and Zherikhin, 1993, Jersimantis Grimaldi, 1997, Kazakhophotina Gratshev and Zherikhin, 1993, and Vitimiphotina Gratshev and Zherikhin, 1993 were of uncertain familial position.

Grimaldi (2003) noted that the Cretaceous mantises largely possess plesiomorphic characters, particularly in regard to their pattern of wing venation, the profemoral brush, the profemoral spines, and/or the protibial spur. It appears as though mantises were in a 'nascent' phase of their evolution during the Early Cretaceous, and that true Mantodea, complete with raptorial forelegs, probably appeared in the Late Jurassic.

Enigmatically, Gorochov (2006) excluded the genera Burmantis and Jersimantis not only from Mantodea but even from Dictyoptera, and mainly owing to the short length of their procoxae (but refer to the emended diagnosis of Burmantis below). Such a conclusion is not supported by a broader swath of character evidence and there is no reason to remove these taxa from the Mantodea, and far less to exclude them from Dictyoptera.

Here we describe various new mantises from the Lower Cretaceous of Spain, Lebanon, and Myanmar. The discovery of this new material permits us to review also relationships among these and other Mesozoic taxa and in relation to the living mantises. Overall the new material further highlights the diversity of Mantodea during 
the Cretaceous and the importance of fossils, despite the paucity of material, for advancing knowledge of mantis evolution.

Fig. 1. Palaeogeographic map showing the provenance of the studied specimens (map after Blackey, 2011). In the text there are detailed information from geology of the outcrops, and the fossil record associated to a new species.

\section{Geological and paleontological settings}

\subsection{Spanish amber}

The new Spanish species was found in the amber-bearing deposit of San Just (Utrillas, Teruel). Spain is rich in amber outcrops of Early Cretaceous age (mainly Albian), but only nine of them have provided fossil arthropods as bioinclusions (Delclòs et al., 2007; Peñalver and Delclòs, 2010). The richest fossil associations have been found in Peñacerrada (Alonso et al., 2000) and El Soplao (Najarro et al., 2009, 2010), in the Basque-Cantabrian Basin, and San Just (Peñalver et al., 2007), in the Maestrazgo Basin (Fig. 1). The amber piece comes from a grey-black claystone level with abundant plant macroremains, such as ferns of the genus Cladophlebis, several conifers such as Arctiopitys, Brachyphyllum, Glenrosa, and Frenelopsis, and ginkgoales such as Eretmophyllum (= Nehvizdya) and Pseudotorellia (B. Gomez, pers. com. 2013). The deposit is situated in the Utrillas Group (sensu Rodríguez-López et al., 2009) which corresponds in this area to a fluvial delta swamp deposit (Querol et al., 1992), wet areas in a fore-erg system (Rodríguez-López et al., 2009). San Just amber was discovered during the last decade (see Peñalver et al., 2007) and up to now those arthropod orders found as inclusions include Acari, Araneae, Blattaria, Isoptera, Orthoptera, Hemiptera, Thysanoptera, Coleoptera, Hymenoptera, Neuroptera and Diptera (Arillo et al., 2008, 2009a, 2009b, 2010, 2012; Engel and Delclòs, 2010; Peñalver and Delclòs, 2010; 
Peñalver and Nel, 2010; Peñalver and Szwedo, 2010; Peñalver et al., 2010; OrtegaBlanco et al., 2011a, 2011b, 2011c; Pérez-de la Fuente et al., 2012; Saupe et al., 2012; Engel et al., 2013; Peris et al., 2014).

\subsection{Lebanese amber}

The Lebanese amber-bearing deposits with bioinclusions are from the Lower Cretaceous, under the "Falaise de Blanche" dated as Ante-Jezzinian (late Barremanianearly Aptian, in Maksoud et al., 2014), and thus the amber is of Barremian age. A number of outcrops (more than 400) have yielded amber but only 22 of these have provided bioinclusions (Azar et al., 2010; Azar, 2012). The new specimen comes from the outcrop of Al-Rihan, Caza Jezzine (Jezzine Department), Mohafazat Loubnan ElJanoubi (South Lebanon Governorate), in southern Lebanon, and where approximately 40 bioinclusions have been found to date. The amber piece comes from a grey sandstone level, while the outcrop has been dated as Ante-Jezzinian (Maksoud et al., 2014). Based on geological and paleontological correlation, the outcrop is situated in the Chouf Sandstone Formation (= Grès de Base or $\mathrm{Cl}$ in older usages), and corresponds to a Barremian fluvial delta deposit. The Al-Rihan amber outcrop was discovered only recently (in 2012 by D.A.). Up to now the following arthropod orders have been found as inclusions in this amber: Acari, Araneae, Archaeognatha, Hemiptera, Blattaria, Mantodea, Orthoptera, Psocoptera, Thysanoptera, Coleoptera, Hymenoptera, Neuroptera, and Diptera.

\subsection{Burmese amber (Myanmar)}


Although Burmese amber has been found from several districts, such as Shwebo, Thayetmyo, Pakoku, and Pegu, it has only been mined and commercialized in the Hukawng Valley (Myitkyina and Upper Chindwin districts) of northern Myanmar (Ross et al., 2010). The new specimen comes from the Noije Bum Hills in the Hukawng Valley and where diverse bioinclusions have been discovered over the years (e.g., Ross et al., 2010; Barden \& Grimaldi, 2014). The mantis originated from a geological section characterized by inter-bedded sandstones, siltstones, shales, micritic limestones, and coal. The age of Burmese amber was considered to be late Albian by Cruikshank and Ko (2003) based on palynomorphs and an ammonite, or lower Cenomanian by Shi et al. (2012) based on volcanic zircons (but consider Ross, 2015; Nicholson et al., 2015). The phylogenetic analysis of ants studied by Barden \& Grimaldi (2014) seems to corroborate the age proposed by Shi et al. (2012). It has been suggested that the resin producer was an araucariacean tree close to the modern Agathis.

Up to now, those arthropod orders found as inclusions are (Rasnitsyn and Ross, 2000; Grimaldi et al., 2002; Ross and York, 2004; Ross et al., 2010; Bonato et al., 2014; Engel and Grimaldi, 2014; Barden and Grimaldi, 2014; Broly et al., 2015; Dunlop et al., 2015; Wunderlich, 2015; Engel et al., 2015a, 2015b): Acari, Araneae, Amblypygi, Solifugae, Thelyphonida, Ricinulei, Opiliones, Pseudoscorpiones, Scorpiones, Geophilomorpha, Scolopendromorpha, Polyxenida, Siphonophorida, Isopoda, Collembola, Zygentoma, Archaeognatha, Ephemeroptera, Odonata, Blattaria, Isoptera, Mantodea, Orthoptera, Phasmatodea, Plecoptera, Dermaptera, Embiodea, Zoraptera, Hemiptera, Psocoptera, Thysanoptera, Raphidioptera, Megaloptera, Mecoptera, Coleoptera, Strepsiptera, Hymenoptera, Neuroptera, Trichoptera, Lepidoptera, and Diptera. 


\section{Material studied and methods}

The Spanish specimen (SJ-10-17) was embedded in a high-quality casting epoxy (Epo-tek 301), according to the protocols of Corral et al. (1999) and Nascimbene and Silverstein (2000), which allowed physical protection and optimal viewing (dorsal and ventral views). The Lebanese specimen (RIH-1E) was prepared in a glass coffin with a medium of Canada balsam and following those protocols described in Azar (2000). The Burmese specimen (NMS, Anderson Collection, National Museums Scotland) was only partially polished and otherwise left untreated. The holotype of Chaeteessites minutissimus Gratshev and Zherikhin, 1993, was restudied and new descriptive information provided herein. The piece of amber was polished on both sides without being embedded.

Descriptions are provided here in the philosophical understanding that descriptive work forms the fundamental basis of comparative sciences and represents the critical data from which broader patterns are derived (Grimaldi and Engel, 2007). Morphological terminology generally follows that of Grimaldi (2003) and Wieland (2013), with various updates to standardize terms across other insect orders (where applicable). The following abbreviations are used for specimens and their official repositories: SJ-10-17, represents the material found in the San Just outcrop and housed at the Fundación Conjunto Paleontológico de Teruel-Dinópolis, Teruel, Spain; RIH-1E, is for that material housed in the Natural History Museum of Lebanese University, Faculty of Sciences II, Fanar, Lebanon; and NMS, is used for National Museums Scotland, Edinburgh, UK. 
All specimens were drawn using an Olympus U-DA drawing tube attached to an Olympus BX51 compound microscope. Photomicrography relied on a digital camera, ColorView III \& Soft Imaging Systems, attached to the same microscope.

\section{Systematic paleontology}

Order: Mantodea Burmeister, 1838

Family: Incertae sedis

Mantodea are considered monophyletic and supported by extensive morphological and molecular data. A few of the autapomorphies proposed by Boudreaux (1979), Klass and Ehrmann (2003), Klass and Eulitz (2007), and Béthoux and Wieland (2009) are observable in fossil specimens, such as: 1) presence of the interantennal sulcus bordering the 'scutellum' (a profoundly ill-named area) of the frons (absent in Blattodea); 2) raptorial forelegs; 3) the profemora with a "femoral brush" (a specialized grooming device located on the antero-distal surface of the profemora), absent in Cretaceous species; 4) presence of the supracoxal sulcus that divides the prothorax into prozona and metazona, and 5) the partial fusion of veins RP and $M$ in the forewing. Mantodeans also exhibit several plesiomorphic characters: 1) three ocelli; 2) pentamerous tarsi (i.e., five tarsomeres); and 3) multi-segmented cerci (Wieland, 2013). Grimaldi (2003) characterized the order Mantodea and based his classification on the following set of characters observable in fossil specimens: 1) pronotum quadrate, saddle-shaped, not covering the head; 2) forelegs spinous, raptorial, and with fully moveable procoxae, and with the protibia bearing a large apical spine or spur; 3) midand hindlegs long, slender, and used in walking, and 4) forewing with a pseudovein (the 
pseudovein is not present in all Recent Mantodea (A.R., pers. obs.), but this does not render it as invalid as a synapomorphy, merely that it is subsequently lost among some higher mantises).

Genus: Aragonimantis gen. nov.

Type species. Aragonimantis aenigma sp. nov.

Type locality. San Just outcrop, Lower Cretaceous (upper Albian) of Teruel (Spain).

Etymology. The new generic name is a combination of Aragón, the Autonomous Community where the San Just amber fossil site is located, and the generic name Mantis, a common stem for names in Mantodea. The gender of the name is feminine.

Diagnosis. Distinguished from other genera known as nymphs in Cretaceous ambers (i.e., Chaeteessites, Electromantis, Jersimantis, Burmantis) mainly on foreleg structure: profemur with ventromesal row of eight stout, short spines, alternating with nine also stout but shorter spines; three relatively short spines (not stiff setae) on ventrolateral edge (the two distal spines are closer together). Protibia with mesal (anteroventral) row of thick spines, increasing in size distad, with well-defined articulation; at apex at least one terminal, thick, posteroventral spine but much shorter (less than 1/5) than apical anteroventral spine. Probasitarsomere shorter than protibia. Coxae covered by spicules. Femoral and tibial cuticles entirely covered with fine, scale-like microsculpture (at least on fore- and mid legs). In addition, ocelli present.

Aragonimantis aenigma sp. nov.

Figs. 2 and 3 
Type locality and horizon. The specimen was found in amber from grey-black claystones with abundant plant remains in the Utrillas Group (sensu Rodríguez-López et al., 2009; Barrón et al., 2015), Lower Cretaceous, middle-upper Albian (sensu Villanueva-Amadoz et al., 2010), upper Albian (E. Barrón, pers. com. 2015), which corresponds to a deposit of a fluvial deltaic swamp. The outcrop of San Just (Peñalver et al., 2007; Peñalver and Delclòs, 2010) is located in the municipality of Utrillas (Teruel Province, Aragón Autonomous Community, eastern Spain).

Holotype. SJ-10-17 (body fossil, anterior half of a nymph) from San Just amber in a prism $23 \times 16 \times 3 \mathrm{~mm}$. The amber fragment $(17 \times 8 \times 3 \mathrm{~mm})$ is dark, with some bubbles and desiccated surfaces brown in colour, containing debris and abundant specimens identical to those found in Cretaceous French ambers which were identified as aerial hyphae of sooty moulds of the genus Metacapnodium (Metacapnodiaceae) (see Girard et al., 2009, 2011). Housed at the Fundación Conjunto Paleontológico de TeruelDinópolis, Spain.

Etymology. Latin aenigma, referring to the inability to assign it to a given family.

Diagnosis. As for genus, with the following additional characters: Antero-ventral row of protibial spines present on distal two-thirds of tibia and comprising ten thick spines having fine longitudinal striation. All anteroventral profemoral spines stout, although of different sizes.

Description (all measures in $\mathrm{mm}$ ). Head globular as observed in ventral and dorsal views, 2.20 width including compound eyes; no processes or ridges observed. Compound eyes large, more or less globular (dimensions $0.76 \times 0.68$ ), protruding laterally from head capsule (exophthalmic), with a large frontal field and inner margins 
close to scape, and consisting of fine, abundant ommatidia. Ocelli present (at least one lateral posterior ocellus visible) (Fig. 2). Frons and clypeus largely obscured. Mandible with three teeth (as figured). Labial palps short, thin, only two distal palpomeres preserved. Maxillary palps well-developed (ca. 1.20 length), with at least four subequal palpomeres (base obscure) (Fig. 3.2). Antenna filiform, incomplete, with symmetrical antennomeres; flagellomere 1 long (longer than scape + pedicel); basal flagellomeres short and compact (length less than width), gradually lengthened apically (Fig. 2).

Pronotum largely incomplete and poorly preserved, apparently without spiculelike setulae; not covering posterior of head. Only fore- and midlegs preserved. Raptorial forelegs complete and well-preserved, unlike midlegs. Left foreleg visible, preserved without deformation, but ventromesal row of spines on profemur not completely visible. Right foreleg cleared, slightly deformed but with entire profemoral ventromesal row preserved (thus it has been possible to reconstruct the foreleg in complete detail: Figs. 2, 3.3-3.6, 4). Procoxal length: 1.10 , width: 0.43 ; procoxa with a dorsal and a ventral antero-apical diverging lobe, with two rows of spines; ventral surface without discoidal spines. Profemora; basal third of profemur slightly inflated and bulbous, lacking a small basal patch of sensillae; with an antero-ventral row of eight stout, short spines, alternating with nine shorter spines; with dense, fine pilosity in ventral furrow; a profemoral grooming device or "femoral brush" not visible, thus distinction between slightly thickened or flattened and scale-like setae not possible. Protibial length: 1.46, width: 0.17 ; protibia with antero-ventral row of ten thick spines increasing in size distad (Fig. 3.3), on distal two-third, having fine longitudinal striation; postero-ventral row of spines not visible, except distalmost spine (of thin setae); distal spines of both anteroand postero-ventral rows thick, with different degrees of development (the last posteroventral spine is less than 1/5 the size of the last anteroventral spine: $0.04 \mathrm{~mm}$ vs. 
$0.24 \mathrm{~mm}$ ), and with well-defined articulations but not spur-like (Fig. 3.4); apicalmost spine (= tibial spur) of anteroventral row as long as 3x width of protibia (Fig. 3.5). Protarsus length: 2.53 (probasitarsus: 1.15); probasitarsus $0.7-0.8 \mathrm{x}$ protibial length; probasitarsus and protarsomere 2 with a small dorsal lobe, and protarsomere 3 with a ventral lobe. Propretarsus with prominent, triangle-shaped arolium; paired claws well developed, with a basal widening (Fig. 3.6). Femoral and tibial cuticles entirely covered with fine scale-like microsculpture (on at least fore- and midlegs) (Fig. 3.7). Cursorial midlegs present. Estimated mesofemoral length: 2.77, width: 0.72; mesofemur approximately as wide as profemur, without spines along its length. Estimated mesotibial length: 2.31 , width: 0.22 ; mesotibia with two large apical spurs, each 0.32 $\mathrm{mm}$ in length (Fig. 3.8), and a ventral row of short, thick spine-like setae. Mesobasitarsus strongly elongate. Abdomen not preserved.

Fig. 2. Aragonimantis aenigma gen. and sp. nov., holotype: SJ-10-17, in ventral habitus and dorsal view of head and anterior margin of pronotum.

Fig. 3. Aragonimantis aenigma gen. and sp. nov., holotype: SJ-10-17. 1) habitus, 2) maxillary palp, 3) left raptorial foreleg, 4) distal part of protibia and its distal spines, 5) detail of protibia and base of tarsus, 6) arolium and distal claws of foreleg pretarsus, 7) midleg surface, 8) distal spine of mesotibia. Scale bars: 1 and 3: $1.5 \mathrm{~mm} ; 5: 1 \mathrm{~mm} ; 2,4,6-8: 200 \mu \mathrm{m}$.

Fig. 4. Reconstruction of forelegs of some Cretaceous mantises. 1) Burmantis sp. (after Grimaldi, 2003, and our observations), 2) Aragonimantis aenigma gen. et sp. nov. (this paper), 3) Jersimantis sp. (after Grimaldi, 2003), 4) Cretomantis larvalis (after Gratshev and Zherikhin, 1993), 5) Chaeteessites minutissimus (after Grimaldi, 2003, and our observations). Not all to the same scale.

Remarks. The profemoral grooming device, or profemoral brush, is present in all modern Mantodea and in some Cretaceous taxa, such as Burmantis, but absent in Jersimantis and Aragonimantis (Fig. 4), and is considered an autapomorphy of Neomantodea. The profemoral brush consists of slightly thickened setae in Burmantis, whereas in more derived taxa, the setae are scale-like and flattened (Wieland, 2013). 
The profemoral brush is also present in the most basal genera of Recent Mantodea such as Chaeteessa, Metallyticus, and Mantoida. Considerable morphological changes occur in the ontogenetic development of this structure. It is present in both nymphal instars and adults, and has feather-shaped setae; their shape does not change in adults, but setae are distinctly longer and increase in number.

The profemora have an antero-ventral row of 17 spines (character " 45 ", state 3 in Wieland, 2013), and this is also found in 'basal' modern genera, such as Chaeteessa and Mantoida, but also in Blattaria and in some fossil species such as Burmantis ssp. and Cretomantis larvalis (Fig. 4).

Mantodeans have a basal, oblique row of one to five spines between the anteriorand posterior-ventral profemoral rows of spines, termed the "discoidal" spines. The modern genus Metallyticus exhibits a single discoidal spine and species of Chaeteessa only two (Wieland, 2013). Discoidal spines are absent in the Cretaceous genera Chaeteessites, Ambermantis, Burmantis, Aragonimantis, Cretomantis, and Jersimantis (Fig. 4), as well as across Blattaria.

Spines on the cursorial meso- and metafemora have been described in the present species as well as Burmantis lebanensis, Jersimantis burmiticus, Cretomantis larvalis, Ambermantis wozniaki, and Santanmantis axelrodi (Hörnig et al., 2013).

Genus Burmantis Grimaldi, 2003

Type species. Burmantis asiatica Grimaldi, 2003, Myanmar.

Remarks. Grimaldi (2003) did not indicate in the original account the length of the procoxa, although he considered them to be short in B. asiatica and B. lebanensis. Based on the new material discussed herein, the procoxa is as is found elsewhere among Mantodea, and its purportedly short stature may have been overstated or misinterpreted 
in the original description (further rendering doubtful Gorochov's (2006) assertions regarding the placement of the genus).

Burmantis lebanensis Grimaldi, 2003

Figs. 5-7

New specimen. Specimen RIH-1E (complete body fossil of a nymph) from Lebanese amber (Figs. 5, 7.1-7.2) mounted in a glass prism $12 \times 8 \times 6 \mathrm{~mm}$ filled with Canada balsam. The amber fragment is transparent and lightly yellow. Housed in the amber collection of the Natural History Museum of the Lebanese University, Faculty of Sciences II (Fanar), Lebanon.

Locality and horizon. Lower Cretaceous, amber of Al-Rihan, Caza Jezzine (Jezzine Department), Mohafazat Loubnan El-Janoubi (South Lebanon Governorate), southern Lebanon (Azar and Nel, 2013). The holotype of B. lebanensis was found at the Bcharreh outcrop, close to the Hasroun village in Barremian clay-sandstones (Maksoud et al., 2014).

Original diagnosis. Differs from B. asiatica by its fewer (4 vs. 10) small spines on the profemur alternating among thicker spines; pronotum and some sclerites covered with small tubercles, instead of minute spiculelike setulae; cerci shorter and with 9-10 (vs. 12) cercomeres and without elongate setae apically.

Description (measures in $\mathrm{mm}$ ). Body coloration: pronotum with two mid-longitudinal bands and mesonotum plus metanotum with mid-level maculations and laterolongitudinal bands; abdomen with two pairs of longitudinal bands (one centro-lateral 
and one lateral); all legs with maculated pattern, mainly proximal and distal maculations as figured (Figs. 5, 7.1).

Head rounded in frontal, dorsal, ventral, and lateral views, width 1.38 including compound eyes and 1.20 high. Compound eyes large, with broad frontal field (compound eye dimensions in frontal view: 0.48 width, 0.69 high; see Fig. 6.1), prominent (exophthalmic); ommatidia not discernible as preserved. Unpaired anterior ocellus present (having strong ocellar setae, see Fig. 6.2), but lateral posterior ocelli not apparent. Frons, clypeus, and labrum preserved (as figured). Mandible with fine teeth (as figured). Labial palps short, thin. Maxillary palps well-developed (ca. 0.60 length), with five palpomeres, subequal in length except palpomere II longer than remainder (Fig. 6.2); galea obscured. Antenna filiform, incomplete (only the two scapes, one pedicel, and a fragment of one flagellum preserved): scape ( 0.18 length $\times 0.09$ width $)$ with three strong distal setae.

Pronotum, mesonotum and metanotum surfaces with scale-like microsculpture having distal margins more sclerotized and finely denticulate (Fig. 6.5); surely they correspond to the small irregular tubercles observed by Grimaldi (2003). Pronotum quadrate, complete and well-preserved (0.87 length, 0.91 width, 0.40 high); not covering head and with chaetotaxy constituted by 19 pairs of short setae (six pairs are marginal) as figured (Fig. 6.5). Mesonotum ca. 0.90 length including the anterior covered portion, 1.21 greatest width and 0.45 high; chaetotaxy constituted by 20 pairs of short setae (11 pairs are marginal) as figured. Metanotum ca. 0.80 length including the anterior covered portion, 1.24 greatest width and 0.42 high with 14 pairs of short setae (11 are marginal) as figured.

Raptorial forelegs complete and well-preserved, except for some portions of tarsi (Fig. 7). Coxae and some indeterminate thoracic sclerites covered by spicules and with 
some strong lateral setae as figured. Procoxal length: 1.00, width: 0.35. Profemoral length: 1.42 , width: 0.34 ; profemur basal third slightly inflated and bulbous, lacking a small, ventro-basal patch of sensillae, but covered by dense, fine pubescence on ventral surface and two longitudinal rows of short spines on dorsal surface (Figs. 4, 6.2), with an anteroventral row of five (maybe four) stout, short spines, alternating with slender setae (Figs. 6.2-6.3, 7.4-7.5); three relatively short spines on postero-ventral edge (the two distal spines are closer together) and a minute spine distally; profemoral brush not visible (present in Burmantis ssp.), thus distinction between slightly thickened or flattened and scalelike setae not possible.

Fig. 5. Burmantis lebanensis Grimaldi, specimen RIH-1E dorsal habitus, showing complete preserved chaetotaxy and body colour pattern, and lateral habitus less detailed.

Protibial length 0.75 , width 0.13 , with a depression in antero-basal position (identical to those observed in Aragonimantis n. gen. and in holotype of $C$. minutissimus from Santonian Siberian amber, E.P., pers. obs.); anteroventral row of 10 thick spines increasing in size distad in distal three-quarters of length (Fig. 7.3), with fine longitudinal striation (Figs. 6.1-6.2); apicalmost spine (length: 0.36, width: 0.04) nearly $2 \mathrm{x}$ width of protibia; posteroventral row of spines well-visible, composed by at least six thin spines, distalmost spine thick (apicalmost spine length $0.17,0.02$ wide) (Fig. 6.2); distal spines of antero- and postero-ventral rows thick, with different degrees of development (one large, one small) and with well-defined points of articulation but not spurlike (Figs. 7.4-7.5). Protarsus: ca. 1.44 long (probasitarsomere 0.72 long); probasitarsus $0.9 \mathrm{x}$ protibial length. [The new specimen has the mesotarsus longer than the mesotibia (considered equal in the original description of the species, but this has not been confirmed through re-examination of the holotype)]. Pretarsus with prominent arolia, paired claws with slight widening basally. Mesofemoral length 2.77, greatest width 0.28 ; mesofemur approximately as wide as profemur, without spines along its 
length. Mesotibial length 1.15 , width 0.15 ; mesotibia with two large spurs, each 0.15 long (as longer as mesotibial width), and an anterior row of short, thick spine-like setae. Mesotarsus 1.51 long. Metatibia 1.68 long (approximately $1.5 \mathrm{x}$ as long as mesotibia). Femoral and tibial cuticles entirely covered with fine scale-like microsculpture (Fig. 6.2). Abdomen complete and well-preserved: short, broad, tergites with short, strong posteromarginal setae as figured (Fig. 5), and fine transverse, linear integumental sculpture; a pair of short (0.38 long), dimerous styli (i.e., two stylomeres); cerci with a thick base, fairly short, composed of $8-9$ cercomeres (as preserved it is not clearly discernable basally for the separation between individual cercomeres), with long setae (except the distal cercomeres) mainly on ventral surface (but shorter than in B. asiatica), and tapered to a fine point (Figs. 5.4; 6.7).

Discussion. The genus Burmantis was based on two nymphs preserved in Cretaceous amber, B. asiatica (upper Albian-lower Cenomanian, Burmese amber) and $B$. lebanensis (Barremian, Lebanese amber). The main diagnostic characters are those of the distinctive foreleg structure (Fig. 4). The two species were differentiated on the basis of the spines, pronotum, and cercal morphology (Grimaldi, 2003). The new specimen from Lebanon is virtually complete and is also a nymph, and finely preserves the forelegs thereby permitting a meaningful comparison with the published account of B. lebanensis. However, we could not observe the antero-distal, profemoral grooming device (profemoral brush) (well visible in B. asiatica and with setae not scale-like, and poorly visible in the holotype of $B$. lebanensis); aside from this genus, this character is known only in post-Cretaceous mantodeans.

Although we are confident that the new specimen belongs to B. lebanensis, it was found at a different locality than the holotype. Based on the new specimen we can 
expand upon the description of this species, mainly in characters of the head, protibia, and abdomen, chaetotaxy of the pronotum, and body coloration. The diagnosis of Burmantis does not require emendation, except to indicate that B. lebanensis has four small antero-ventral profemoral spines alternating with five thick spines, but clearly less (nearly half) than those in B. asiatica. Grimaldi (2003) apparently observed a separation in the middle of each of the two thin and elongate distal cercomeres and he therefore figured a partially visible cercus with at least eight cercomeres. In the new specimen it appears clear that this was an artifact (see Figs. 6.4 and 7.7), and we therefore consider the species as possessing 8-9 cercomeres. Ontological changes in the cercus are known from a variety of genera and it is possible that the holotype of B. lebanensis and specimen RIH-1E represent different instars.

All three diagnostic characters of Burmantis were documented fully from only the type species (B. asiatica) in the original account of the genus. However, we were able to observe them in the new specimen of B. lebanensis, therefore confirming its placement therein: 1) apex of protibia with two long, thick, anterior- and posterior-ventral setae; 2) probasitarsus slightly shorter than protibia [Note that there is an error in the original diagnosis as the probasitarsus of this genus is not slightly "longer", as is also clear from the original description and figures of the type species]; and 3) at least an anterior ocellus present.

Fig. 6. Burmantis lebanensis Grimaldi, specimen RIH-1E. 1) head and raptorial left foreleg in frontal view, 2) same in ventral view, 3) right profemur in externo-lateral view (five arrows indicate five stout, short spines of ventromesal row), 4) genitalia in lateral view showing cercal colour pattern (styli have been highlighted), 5) thoracic nota in dorsal view, showing colour pattern, complete chaetotaxy, and two details of scale-like microsculpture. Scale bars: 1-2: 1 $\mathrm{mm}, 3-7: 200 \mu \mathrm{m}$.

Fig. 7. Burmantis lebanensis Grimaldi, specimen RIH-1E. 1) habitus in dorsal view, 2) habitus in ventral view, 3) protibia showing distribution of spines, 4) right profemur in externo-lateral view showing the anteroventral row of spines and some stiff setae, 5) same area at different focal plane and showing spines on posteroventral profemoral edge, 6) lateral view of genitalia depicting a stylus in plane of focus, 7) ventral view of cercus. 
Other newly observed characters further differentiate B. asiatica from B. lebanensis: 1) the apicalmost spine is nearly $2 \mathrm{x}$ as wide as the protibia in $B$. asiatica, versus $3 \mathrm{x}$ in $B$. lebanensis and $A$. aenigma; 2) the anteroventral protibial row has 10 spines in $B$. lebanensis, compared to eight in B. asiatica; 3) B. lebanensis has a posteroventral protibial row of spines with at least six spines, versus nine in $B$. asiatica, and 4) $B$. lebanensis has 8-9 cercomeres, rather than $B$. asiatica where there are 12 cercomeres (the shape of the individual cercomeres also differs between the species: see Grimaldi, 2003).

Burmantis zherikhini sp. nov.

Figs. 8 and 9

2010 'First adult praying mantis (Mantodea, front end only)', in Ross et al., p. 214, fig. $3 \mathrm{~A}$.

Locality and horizon. Burmese amber, upper Albian-lower Cenomanian (but consider Ross, 2015; Nicholson et al., 2015). Noije Bum Hills, Hukawng Valley, northern Myanmar.

Holotype. Incomplete body fossil of an adult (Figs. 8.1, 9.1) in a runnel fragment of Burmese amber formed by highly liquid resin, $8 \times 7 \times 3 \mathrm{~mm}$ in size, partially polished. Specimen no. NMS G.2010.20.8, purchased from Scott Anderson. The amber is transparent, lightly red, and with a cluster of abundant plant trichomes. Housed at the National Museums Collection Centre, National Museums Scotland, Edinburgh.

Etymology. The specific epithet honors the memory of Dr. Vladimir V. Zherikhin (1945-2001) for his valuable contributions to the study of fossil Mantodea as well as Burmese amber. 
Diagnosis. The species is distinctive within the genus for its elongate maxillary palps, subequal anteroventral and posteroventral terminal protibial spines, and posteroventral profemoral setae slightly barbed and having fine, longitudinal striation.

Description (dimensions in $\mathrm{mm}$ ). Incomplete alate, consisting of head, prothorax, left foreleg, a partial mid leg, and wing bases (Figs. 8.1, 9.1). Body coloration not preserved.

Head length ca. 1.5, width ca. 1.60 (including compound eyes). Compound eyes large, bulbous (dimensions $1.07 \times 0.56$ in lateral view), with broad frontal field, prominent (exophthalmic) (Fig. 8.1); fine, abundant, well-preserved ommatidia. Three ocelli present (not easily visible as preserved). Frons, clypeus, and labrum wellpreserved. Labial palp long (only distal palpomeres visible in lateral view). Maxillary palp long (ca. 1.70 length), with five, subequal palpomeres (Figs. 8.1, 9.2); galea and lacinia well-developed (Fig. 8.1). Antenna filiform (apexes incomplete), left with basal $4.5 \mathrm{~mm}$ preserved (with about 23 flagellomeres); one distal antennal fragment (of ca. 25 antennomeres) overlying left forewing: scape ca. 0.26 length $\mathrm{x} 0.10$ width, pedicel 0.27 length $\times 0.08$ width; first flagellomere 0.22 length; remainder of flagellomeres slightly shorter; flagellomeres with scale-like microsculpture.

Pronotum not covering head, with scale-like microsculpture, a few marks of coloration, and abundant short setae (Fig. 8.2). Fore- and midlegs with scale-like microsculpture; left procoxa elongate, length 1.75. Profemoral length: 2.14, basal width: 0.47; basal third slightly inflated, apparently lacking a small, ventro-basal patch of sensillae, but covered by dense, fine pubescence on ventral surface and at least a longitudinal row of short spines on dorsal surface (Figs. 8.3); mesially with a brush composed of minute scales (Fig. 8.3) (but its position is more basal than would be 
expected); with an antero-ventral row of five stout, short spines, alternating with shorter spines that differ in orientation and slightly more marginal insertions (Fig. 8.3); three relatively short, setose spines on postero-ventral edge (Figs. 8.3 detail, and 9.3-9.4) (the two proximal spines are closer together), and a minute spine distally (as in $B$. lebanensis); profemoral brush apparently absent (if this can be confirmed, then this is either indicative of an ontological difference between nymphs and adults, or indicative of a possible misplacement within Burmantis). Protibial length: 1.38, width: 0.13; anteroventral row with nine thick spines increasing in size distally in distal two-thirds of length, apicalmost spine (length: 0.30 ) nearly $2 \mathrm{x}$ as wide as protibia; posterior-ventral row of spines well-visible, composed of at least three thin spines, distalmost spine thick (the apicalmost spine is length: 0.36) (Fig. 8.4); distal spines of antero- and posterior ventral rows thick, with different degrees of development (one large, one small), and with well-defined points of articulation but not spurlike. Probasitarsus complete, long and thin, articulation with second protarsomere obscure; terminal protarsomeres missing. Mesofemur and mesotibia with spurs. Base of left wing with only $2.8 \mathrm{~mm}$ preserved, with main veins and corrugated intercalaries, main veins with a peculiar circular microsculpture (likely preservational).

Discussion. All of the original diagnostic characters of the genus Burmantis are observable in the new species but the relative sizes of the protibia and the probasitarsus cannot be measured. The new species can be distinguished from B. lebanensis on the basis of the length of the maxillary palpomeres and the length of the two spines at the apex of the protibia, being subequal in B. zherikhini while in B. lebanensis the distal anteroventral spine is half the length of the distal posteroventral spine. Burmantis zherikhini may be distinguished from both $B$. asiatica and $B$. lebanensis by the 
posteroventral profemoral row of spines striated and barbed, and in the number of spines in the anteroventral profemoral row. In addition, the insertion tubercle of the distal anteroventral spine of the profemur is open in $B$. zherikhini while it is closed in $B$. asiatica and B. lebanensis.

Remarks. The holotype of B. zherikhini is the first adult discovered for the genus Burmantis, and is interesting for its small size as it was assumed that small nymphs should represent young instars based solely on their size. The present adult indicates that the previously documented nymphal instars could actually represent later instars than originally assumed. Some modern Mantodea have small adults, but hatch as relatively large first instars (Wieland, 2013).

The presence of a distal posteroventral (not anteroventral as in Wieland, 2010, 2013) spine on the protibia in the adult of $B$. zherikhini is also interesting as it was assumed Wieland (2013: 32) that it could represent an adaptation of young nymphs as 'a demand of capturing very small preys'. In fact, Wieland (2013) considered this character widespread among modern mantodean nymphs although not present in adults.

Fig. 8. Burmantis zherikhini sp. nov., holotype NMS G.2010.20.8. 1) head and anterior part of thorax in lateral view, 2) pronotum in lateral view showing colour pattern, chaetotaxy, and a detail of its scale-like microsculpture, 3) raptorial foreleg most likely showing a brush (see arrow and area magnified) comprised of minute scales (this structure was not observed with confidence) and detail of first posteroventral profemoral spine.

Fig. 9. Burmantis zherikhini sp. nov., holotype NMS G.2010.20.8 (photographs by Bill Crighton). 1) habitus, 2) maxillary palp, 3) first posteroventral profemoral spine, 4) detail of same spine with higher magnification. Scale bars: 1: $1 \mathrm{~mm}, 2-4: 200 \mu \mathrm{m}$.

\section{Phylogenetic analysis}

List of characters (selected after Grimaldi, 2003, and Wieland, 2013) (Table 2).

- Character 1: Foreleg cursorial (0); Raptorial forelegs spiny and folded under thorax at rest, with associated movable procoxa (from Grimaldi, 2003) (1). Secondarily the 
forelegs of some extant mantises could be adapted to locomotion owing to their habitat (e.g., Mantoida, Chaeteessa, Metallyticus) but are coded as based on their overall morphology and use in life.

- Character 2: Mesofemur raptorial (0); not raptorial (1). This character corresponds to character 5 of Grimaldi (2003).

- Character 3: Discoidal spine of profemora absent (0); present (1). This character corresponds to character 14 of Grimaldi (2003).

- Character 4: Profemur with claw groove for containment of anterodistal protibial spur when leg is closed (0); present (1).

- Character 5: Large distal posteroventral protibial spine present only in early instars (e.g., Metallyticus, Mantoida, Humbertiella, among others) (0); retained in the adults (1).

- Character 6: Cerci not greatly developed (with 8-15 cercomeres) (0); long (more than 20 cercomeres) (1).

- Character 7: Profemur with a row of numerous short spines (0); with a row of 3-4 long spines (1).

- Character 8: Anteroventral profemoral composed of just a row of stiff setae (0); row composed of 5-6 spines alternating with short spines or stiff setae (1).

Some of the characters by Grimaldi (2003) were eliminated as they were ambiguously defined, nearly impossible to observe on the fossils, or with an unclear polarization. For example, those characters concerning the ocelli and the profemoral brush were not coded as they are difficult to observe in fossils (even when a fossil is well-preserved) and therefore introduce a large number of uncertain codings (characters 12 and 19 in Grimaldi, 2003). Moreover, the profemoral brush is even difficult to 
observe in extant specimens (see fig. 25b in Grimaldi, 2003). Similarly, given that the frons is poorly preserved in our and many other fossil mantises, the presence/absence or development of ocelli is often uncertain. Grimaldi (2003) noted Burmantis as having state "?", while in the figures at least one ocellus is preserved in B. asiatica suggesting some degree of a lack of confidence with the character and its coding.

In addition, characters of wing venation were not coded as most of them are impossible to code across the majority of the Cretaceous fossil species as they are either known only from nymphs or do not have wings fully preserved. Lastly, the length of the tarsomeres depends greatly on ecological adaptations of the species and is therefore highly homoplastic.

Most of those characters employed by Wieland (2013) are pertinent only to distinguish among lineages of extant mantises and serve no purpose for resolving issues among the Cretaceous taxa (the result being that all Cretaceous taxa would be coded as 0 or ?). Given the above, we chose to produce a greatly reduced matrix and focus on the Cretaceous and basal living taxa.

Character 5 in our table could be quite important, as Wieland (2013) considers a posteroventral row of spines in the protibia in some small nymphs an adaptation for hunting small-sized prey, and this then is not found in adults of the same species. However, the adult of $B$. zherikhini retains this otherwise "nymphal" trait, perhaps due to its minute size. We consider that those Cretaceous genera with a posteroventral protibial "claw" should be coded as (1), although only nymphs are known (they share also character 7).

The data matrix used for the analysis consists of 16 taxa (one outgroup, Baissomantis, and 15 ingroup taxa), and the aforementioned 8 characters. We preferred to choose the fossil taxon Baissomantis as the outgroup rather than a hypothetical 
ancestor, as in Grimaldi (2003), because it lends less a priori bias to the analysis. Baissomantis are one of the oldest representatives of the mantodean stem-group. The chosen ingroup consists of representatives of the most inclusive modern mantis clades, and the fossil taxa have been selected for their completeness. Characters were treated as non-additive and unordered. The matrix was constructed with Nexus, version 0.5.0 (2001) and subjected to cladistic analysis using Paup* 4.0b10, utilizing the Branch and Bound search method. The analysis not surprisingly recovered 6436 equally parsimonious topologies (given the larger number of taxa relative to the number of characters), with a length of 13 steps, $\mathrm{CI}=0.84$ (CI excluding uninformative characters $=0.81$ ), and $\mathrm{RI}=0.9$. The strict consensus is completely unresolved (Fig. 10). Although of only heuristic value, a 50\% majority-rule consensus resolves as follows: [((remaining Mantodea \& Amorphoscelis \& Chaeteessa \& (Mantoida + Metallyticus)) + Ambermantis $) \&($ Cretomantis + Santanmantis $) \&($ Burmantis + Aragonimantis $) \&$ Chaeteessites \& Electromantis \& Jersimantis \& Cretophotina \& Baissomantis].

The only clades present in the majority-rule tree concern the Recent taxa and two small clades: (Cretomantis + Santanmantis) and (Burmantis + Aragonimantis). The clade of (Cretomantis + Santanmantis) is not supported by any putative unambiguous synapomorphy in the consensus topology, while (Burmantis + Aragonimantis) was supported in those topologies by character 8 , state 1 , and potentially only present in these taxa, but with some doubt about its presence in Mantoida, Cretophotina, Chaeteessites, and Baissomantis. The clade (Mantoida + Metallyticus) was also not supported by any unambiguous synapomorphy in the consensus topology. The clade of ((remaining Mantodea \& Amorphoscelis \& Chaeteessa \& (Mantoida + Metallyticus $))+$ Ambermantis) was supported by character 7 , state 1 , but it is also unknown in most other taxa and therefore not indicative of much. The clade of (remaining Mantodea \& 
Amorphoscelis \& Chaeteessa \& (Mantoida + Metallyticus)) was supported by state 1 of characters 3 and 4, also unknown in Cretophotina and Baissomantis. While of merely heuristic value, the 50\% majority-rule topology also provides little insight.

Obviously, the lack of sufficient characters (merely 8 characters for 16 taxa) is the main difficulty with the present analysis as is the lack of codings for most cells in the matrix (48 for 240 character states, i.e., $20 \%$ of the whole matrix). Nevertheless, earlier analyses with slightly more data, albeit dubiously coded at times, fared similarly with most taxa in large polytomies (e.g., Grimaldi, 2003, who used 26 morphological characters for 20 taxa and arrived at a strict consensus almost completely unresolved).

Fig. 10. 50\% majority rule consensus cladogram of studied Cretaceous mantis genera.

\section{Conclusions}

One could attempt various weighting schemes or impose models whereby certain character transitions are a priori imposed (e.g., losses allowed but re-acquisition prevented), but in the absence of developmental or other forms of data there is no justification for such an extreme step. Ultimately, the most productive means for resolving these relationships is the discovery of new material - new species and more completely preserved material of already known taxa. These facts highlight the importance of renewed paleontological fieldwork alongside more extensive comparative morphological treatments to discover and elucidate new character systems for Mantodea.

\section{Acknowledgements}


We thank the staff of the "Fundación Conjunto Paleontológico de TeruelDinópolis" for curation and access to the Spanish specimen and A.P. Rasnitsyn for permitting us to study the holotype of Chaeteessites minutissimus. Thanks also to Bill Crighton (NMS volunteer) for photographing the holotype of B. zherikhini. Paleontological excavations in the San Just outcrop were sponsored by "Diputación General de Aragón" and "Caja Rural de Teruel". This study was supported by the Spanish Ministry of Economy and Competitiveness projects CGL2011-23948 to X.D., and CGL2014-52163 to X.D. and E. Barrón, and is a contribution of the team project "Biodiversity: Origin, Structure, Evolution and Geology" (granted to D.A. by the Lebanese University) and the Division of Entomology, University of Kansas Natural History Museum. The participation of M.S.E. was supported by U.S. National Science Foundation grants DEB-1144162 and DBI-1304957 (both to M.S.E.). Authors wish also to express their gratitude to the anonymous reviewers and to the Editor Dr. E. Koutsoukos for their helpful comments and input, that considerably improved the manuscript.

\section{References}

Alonso, J., Arillo, A., Barrón, E., Corral, J.C., Grimalt, J., López, J.F., López, R., Martínez-Delclòs, X., Ortuño, V.M., Peñalver, E., Trincão, P.R., 2000. A new fossil resin with biological inclusions in Lower Cretaceous deposits from Álava (Northern Spain, Basque-Cantabrian Basin). Journal of Paleontology 74, 158-178.

Arillo, A., Peñalver, E., Delclòs, X., 2008. Microphorites (Diptera, Dolichopodidae) from the Lower Cretaceous amber of San Just (Spain), and the co-occurrence of two ceratopogonid species in Spanish amber deposits. Zootaxa 1920, 29-40.

Arillo, A., Peñalver, E., García-Gimeno, V., 2009a. First fossil Litoleptis (Diptera: Spaniidae) from the Lower Cretaceous amber of San Just (Teruel Province, Spain). Zootaxa 2026, 33-39.

Arillo, A., Subías, L.S., Shtanchaeva, U., 2009b. A new fossil species of oribatid mite, Ametroproctus valeriae sp. nov. (Acariformes, Oribatida, Ametroproctidae), from the Lower Cretaceous amber of San Just, Teruel Province, Spain. Cretaceous Research $30,322-324$. 
Arillo, A., Subías, L.S., Shtanchaeva, U., 2010. A new genus and species of oribatid mite, Cretaceobodes martinezae gen. et sp. nov. from the Lower Cretaceous amber of San Just (Teruel Province, Spain) (Acariformes, Oribatida, Otocepheidae). Paleontological Journal 44, 287-290.

Arillo, A., Subías, L.S., Shtanchaeva, U., 2012. A new species of fossil oribatid mite (Acariformes, Oribatida, Trhypochthoniidae) from the Lower Cretaceous amber of San Just (Teruel Province, Spain). Systematic \& Applied Acarology 17, 106-112.

Azar, D., 2000. Les ambres mésozoïques du Liban. PhD thesis. University Paris-XI, Orsay, France, (164 pp. + 148 pp. annexes).

Azar, D., 2012. Lebanese amber: A "Guinness Book of Records". Annales Universitatis Paedagogicae Cracoviensis, Folia 111, 44-60.

Azar, D., Nel, A., 2013. A new beaded lacewing from a new Lower Cretaceous amber outcrop in Lebanon (Neuroptera: Berothidae), in: Azar, A., Engel, M.S., Jarzembowski, E., Krogmann, L., Nel, A., Santiago-Blay, J. (Eds.), Insect Evolution in an Amberiferous and Stone Alphabet (Proceedings of the 6th International Congress on Fossil Insects, Arthropods and Amber). Brill. Leiden - Boston, pp. 111130.

Azar, D., Gèze, R., Acra, F., 2010. Lebanese amber, in: D. Penney (Ed.), Biodiversity of fossils in amber from the major world deposits. Siri Scientific Press, Manchester, pp 271-298.

Barden, Ph., Grimaldi, D., 2014. A Diverse Ant Fauna from the Mid-Cretaceous of Myanmar (Hymenoptera: Formicidae). PLoS One 9(4), e93627, doi:10.1371/journal.pone.0093627

Barrón, E., Peyrot, D., Rodríguez-López, J.P., Meléndez, N., López del Valle, R., Najarro, M., Rosales, I., Comas-Rengifo, M.J., 2015. Palynology of Aptian and upper Albian (Lower Cretaceous) amber-bearing outcrops of the southern margin of the Basque-Cantabrian basin (northern Spain). Cretaceous Research 52, 292-312.

Beier, M., 1967. Mantis religiosa L. im Pliozän des Harzvorlandes. Berichte der Naturhistorischen Gesellschaft Hannover 111, 63-64.

Beier, M., 1968. Mantodea (Fangheuschrecken). Handbuch der Zoologie, vol. IV, Band: Arthropoda, 2 Hälfte: Insecta. Zweite Auflage. 47 pp.

Béthoux, O., 2005. Cnemidolestodea (Insecta): an ancient order reinstated. Journal of Systematic Palaeontology 3, 403-408.

Béthoux, O., Wieland, F., 2009. Evidence for Carboniferous origin of the order Mantodea (Insecta: Dictyoptera) gained from forewing morphology. Zoological Journal of the Linnean Society 156, 79-113.

Béthoux, O., Beckemeyer, R.J., Engel, M.S., Hall, J.D., 2010. New data on Homocladus grandis, a Permian stem-mantodean (Polyneoptera: Dictyoptera). Journal of Paleontology 84, 746-753.

Blakey, R.C., 2011. Global paleogeographic views of earth history: Late Precambrian to Recent. http://cpgeosystems.com/paleomaps.html (Accessed 24/09/2015).

Bonato, L., Edgecombe, G.D., Minelli, A., 2014. Geophilomorph centipedes from the Cretaceous amber of Burma. Palaeontology 57, 97-110.

Boudreaux, H.B., 1979. Arthropod phylogeny with special reference to insects. Wiley \& Sons. New York, Chichester, Brisbane, Toronto, 320 pp.

Broly, P., Maillet, S., Ross, A.J., 2015. The first terrestrial isopod (Crustacea: Isopoda: Oniscidea) from Cretaceous Burmese amber of Myanmar. Cretaceous Research 55, $220-228$. 
Corral, J.C., López del Valle, R., Alonso, J., 1999. El ámbar cretácico de Álava (Cuenca Vasco-Cantábrica, norte de España). Su colecta y preparación. Estudios del Museo de Ciencias Naturales de Álava 14 (special number 2), 7-21.

Cruickshank, R.D., Ko, K., 2003. Geology of an amber locality in the Hukawng Valley, northern Myanmar. Journal of Asian Earth Sciences 21, 441-455.

Deitz, L.L., Nalepa, C., Klass, K.D., 2003. Phylogeny of the Dictyoptera re-examined (Insecta). Entomologische Abhandlungen 61, 69-91.

Delclòs, X., Arillo, A., Peñalver, E., Barrón, E., Soriano, C., López del Valle, R., Bernárdez, E., Corral, C., Ortuño, V.M., 2007. Fossiliferous amber deposits from the Cretaceous (Albian) of Spain. Comptes Rendus Palevol 6, 135-149.

DeSalle, R., 1994. Implications of ancient DNA for phylogenetic studies. Experientia 50, 543-550.

Dunlop, J.A., Bird, T.L., Brookhart, J.O., Bechly, G., 2015. A camel spider from Cretaceous Burmese amber. Cretaceous Research 56, 265-273.

Ehrmann, R., 1999. Gottesanbeterinnen in Kopal und Bernstein (Insecta: Mantodea). Arthropoda 7, 2-8.

Ehrmann, R., 2002. Mantodea: Gottesanbeterinnen der Welt. Natur und Tier, Munich, $519 \mathrm{pp}$.

Engel, M.S., Delclòs, X., 2010. Primitive termites in Cretaceous amber from Spain and Canada (Isoptera). Journal of the Kansas Entomological Society 83, 111-128.

Engel, M.S., Grimaldi, D.A., 2014. Whipspiders (Arachnida: Amblypygi) in amber from the Early Eocene and mid-Cretaceous, including maternal care. Novitates Paleoentomologicae 9, 1-17.

Engel, M.S., Grimaldi, D.A., Krishna, K., 2009. Termites (Isoptera): Their phylogeny, classification, and rise to ecological dominance. American Museum Novitates 3650, $1-27$.

Engel, M.S., Huang, D., Breitkreuz, L.C.V., Cai, C., Alvarado, M., 2015a. Two new species of mid-Cretaceous webspinners in amber from northern Myanmar (Embiodea: Clothodidae, Oligotomidae). Cretaceous Research in press.

Engel, M.S., Huang, D., Breitkreuz, L.C.V., Azar, D., Cai, C., Alvarado, M., 2015b. A new twisted-wing parasitoid from mid-Cretaceous amber of Myanmar (Strepsiptera). Cretaceous Research in press.

Engel, M.S., Ortega-Blanco, J., Soriano, C., Grimaldi, D.A., Delclòs, X., 2013. A new lineage of enigmatic diaprioid wasps in Cretaceous amber (Hymenoptera: Diaprioidea). American Museum Novitates 3771, 1-23.

Girard, V., Néraudeau, D., Adl, S.M., Breton, G., 2011. Protist-like inclusions in amber, as evidenced by Charentes amber. European Journal of Protistology 47, 59-66.

Girard, V., Schmidt, A.R., Struwe, S., Perrichot, V., Breton, G., Néraudeau, D., 2009. Taphonomy and palaeoecology of mid-Cretaceous amber-preserved microorganisms from southwestern France. Geodiversitas 31, 153-162.

Gorochov, A.V., 2006. New and little known orthopteroid insects (Polyneoptera) from fossil resins: communication 1. Paleontological Journal 40, 646-654.

Gorochov, A.V., 2013. No evidence for Paleozoic origin of mantises (Dictyoptera: Mantina). Zoosystematica Rossica 22, 6-14.

Gratshev, V.G., Zherikhin, V., 1993. New fossil mantids (Insecta, Mantida [SIC]). Paleontological Journal 27, 148-165.

Grimaldi, D., 1997. A fossil mantis (Insecta: Mantodea) in Cretaceous amber of New Jersey, with comments on the early history of the Dictyoptera. American Museum Novitates 3204, 1-11. 
Grimaldi, D., 2003. A revision of Cretaceous mantises and their relationships, including new taxa (Insecta: Dictyoptera: Mantodea). American Museum Novitates 3412, 147.

Grimaldi, D., Engel, M.S., 2005. Evolution of the Insects. Cambridge University Press, Cambridge, $755 \mathrm{pp}$.

Grimaldi, D., Engel, M.S., 2007. Why descriptive science still matters. BioScience 57, 646-647.

Grimaldi, D.A., Engel, M.S., Nascimbene, P.C., 2002. Fossiliferous Cretaceous amber from Myanmar (Burma): Its rediscovery, biotic diversity, and paleontological significance. American Museum Novitates 3361, 1-71.

Guan Z., Prokop, J., Lapeyrie, J., Roques, P., Nel, A., 2015. Revision of the enigmatic insect family Anthracoptilidae enlightens the evolution of Palaeozoic stemdictyopterans. Acta Palaeontologica Polonica, doi: http://dx.doi.org/10.4202/app.00051.2014.

Handlirsch, A. 1922. Animalia Insecta Palaeozoica. Fossilium Catalogus, W. Junk, Berlin, $230 \mathrm{pp}$.

Hörnig, M.K., Haug, J.T., Haug, C., 2013. New details of Santanmantis axelrodi and the evolution of the mantodean morphotype. Palaeodiversity 6, 157-168.

Inward, D., Beccaloni, G., Eggleton, P., 2007. Death of an order: A comprehensive molecular phylogenetic study confirms that termites are eusocial cockroaches. Biology Letters 3, 331-335.

Kambhampati, S., 1995. A phylogeny of cockroaches and related insects based on DNA sequence of mitochondrial ribosomal RNA genes. Proceedings of the National Academy of Sciences, USA 92, 2017-2020.

Kevan, D.K. McE., 1977. The higher classification of the orthopteroid insects. Memoirs of the Lyman Entomological Museum and Research Laboratory 4 (special publication 12), 1-52.

Klass, K.D., 1997. The external male genitalia and the phylogeny of Blattaria and Mantodea. Bonner zoologische Monographien 42, 1-341.

Klass, K.D., 2000. The male abdomen of the relic termite Mastotermes darwinensis (Insecta: Isoptera: Mastotermitidae). Zoologishcer Anzeiger 239, 231-262.

Klass, K.D., Ehrmann, R., 2003. 13. Ordnung Mantodea, Fangschrecken, Gottesanbeterinnen, in: Dathe, H.H. (Ed.), Lehrbuch der Speziellen Zoologie, Band I: Wirbellose Tiere, 5. Teil: Insecta, Spektrum, Heidelberg, Berlin, pp. 182-197.

Klass, K.D., Eulitz, U., 2007. The tentorium and anterior head sulci in Dictyoptera and Mantophasmatodea. Zoologischer Anzeiger 246, 205-234.

Krishna, K., Grimaldi, D.A., Krishna, V., Engel, M.S., 2013. Treatise on the Isoptera of the world. Bulletin of the American Museum of Natural History 377, 1-2704.

Kukalová-Peck, J., Beutel, R.G., 2012. Is the Carboniferous $\dagger$ Adiphlebia lacoana really the "oldest beetle"? Critical reassessment and description of a new Permian beetle family. European Journal of Entomology 109, 633-645.

Legendre, F., Nel, A., Svenson, G.J., Robillard, T., Pellens, R., Grandcolas, P., 2015. Phylogeny of Dictyoptera: dating the origin of cockroaches, praying mantises and termites with molecular data and controlled fossil evidence. PLoS One 10 (7), (e0130127), $27 \mathrm{pp}$.

Lo, N., Bandi, C., Watanabe, H., Nalepa, C., Beninati, T. 2003. Evidence for cocladogenesis between diverse dictyopteran lineages and their intracellular endosymbionts. Molecular Biology and Evolution 20, 907-913. 
Lo, N., Tokuda, H., Watanabe, H., Rose, H., Slaytor, M., Maekawa, K., Bandi, C., Noda, H., 2000. Evidence from multiple gene sequences indicated that termites evolved from wood-feeding cockroaches. Current Biology 10, 801-804.

Maksoud, S., Granier, B., Azar, D., Gèze, R., Paicheler, J.-C., Moreno-Bedmar, J.A., 2014. Revision of "Falaise de BLANCHE" (Lower Cretaceous) in Lebanon, with the definition of a Jezzinian Regional Stage. Carnets de Géologie [Notebooks on Geology] 14, 401-427.

Martynov, A.V. 1938. Etude sur l'histoire géologique et de phylogénie des ordres des insectes (Pterygota). Première partie. Palaeoptera et Neoptera-Polyneoptera [in Russian, with French summary]. Trudy Paleontologicheskogo Instituta Akademii nauk SSSR, Moscow 7 (4): 1-149.

Meyer, H.W., 2003. The Fossils of Florissant. Smithosonian Books, Washington. 258pp.

Misof, B., Liu, Shanlin, Meusemann, K., Peters, R.S., Donath, A., Mayer, C., Frandsen, P.B., Ware, J., Flouri, T., Beutel, R.G., Niehuis, O., Petersen, M., IzquierdoCarrasco, F., Wappler, T., Rust, J., the 1KITE consortium (83 other authors), Wang, J., Kjer, K.M., Zhou, X., 2014. Phylogenomics resolves the timing and pattern of insect evolution. Science 346, 763-767.

Najarro, M., Peñalver, E., Rosales, I., Pérez-de la Fuente, R., Daviero-Gomez, V., Gomez, B., Delclòs, X., 2009. Unusual concentration of Early Albian arthropodbearing amber in the Basque-Cantabrian Basin (El Soplao, Cantabria, northern Spain): Palaeoenvironmental and palaeobiological implications. Geologica Acta 7, 363-387.

Najarro, M., Peñalver, E., Rosales, I., Pérez-de la Fuente, R., Menor-Salván, C., Soriano, C., Barrón, E., López del Valle, R., Ortega-Blanco, J., Delclòs, X., 2010. A review of the El Soplao amber outcrop, Early Cretaceous of Cantabria (Spain). Acta Geologica Sinica (English Edition) 84, 959-976.

Nascimbene, P., Silverstein, H., 2000. The preparation of fragile Cretaceous ambers for conservation and study of organismal inclusions, in: D. Grimaldi (Ed.), Studies on Fossils in Amber, with Particular Reference to the Cretaceous of New Jersey. Backhuys Publishers, Leiden, pp. 93-102.

Nel, A., Roy, R., 1996. Revision of the fossil "mantid" and "ephemerid" species described by Piton from the Palaeocene of Menat (France) (Mantodea: Chaeteessidae, Mantidae, Ensifera: Tettigonioidea). European Journal of Entomology 93, 223-234.

Nicholson, D.B., Mayhew, P.J., Ross, A.J., 2015. Changes to the fossil record of insects through fifteen years of discovery. PLoS One, DOI: 10.1371/journal.pone.0128554.

Ortega-Blanco, J., Delclòs, X., Engel, M.S., 2011a. Diverse stigmaphronid wasps in Early Cretaceous amber from Spain (Hymenoptera: Ceraphronoidea: Stigmaphronidae). Cretaceous Research 32, 762-773.

Ortega-Blanco, J., Delclòs, X., Peñalver, E., Engel, M.S., 2011b. Serphitid wasps in Early Cretaceous amber from Spain (Hymenoptera: Serphitidae). Cretaceous Research 32, 143-154.

Ortega-Blanco, J., Peñalver, E., Delclòs, X., Engel, M.S., 2011c. False fairy wasps in Early Cretaceous amber from Spain (Hymenoptera: Mymarommatoidea). Palaeontology 54, 511-523.

Pellens, R., D’Haese, C., Bellés, X., Piulachs, M.D., Legendre, F., Wheeler, W., Grandcolas, P., 2007. The evolutionary transition from subsocial to eusocial behavior: phylogenetic and ecological evidence for modification of the shift- 
independent-care hypothesis with a new prototermite model. Molecular Phylogenetics and Evolution 43, 616-626.

Peñalver, E., Delclòs, X., 2010. Spanish Amber, in: D. Penney (Ed.), Biodiversity of fossils in amber from the major world deposits. Siri Scientific Press, Manchester, pp. 236-270.

Peñalver, E., Nel, P., 2010. Hispanothrips from Early Cretaceous Spanish amber, a new genus of the resurrected family Stenurothripidae (Insecta: Thysanoptera). Annales de la Société entomologique de France 46, 138-147.

Peñalver E., Szwedo J., 2010. Perforissidae (Hemiptera: Fulgoroidea) from the Lower Cretaceous San Just amber (Eastern Spain). Alavesia 3, 97-103

Peñalver, E., Delclòs, X., Soriano, C., 2007. A new rich amber outcrop with palaeobiological inclusions in the Lower Cretaceous of Spain. Cretaceous Research 28, 791-802.

Peñalver, E., Ortega, J., Nel, A., Delclòs, X., 2010. Mesozoic Evaniidae (Insecta: Hymenoptera) in Spanish amber: Reanalysis of the phylogeny of the Evanioidea. Acta Geologica Sinica (English Edition) 84, 809-827.

Pérez-de la Fuente, R., Peñalver, E., Delclòs, X., Engel, M.S., 2012. Snakefly diversity in Early Cretaceous amber from Spain (Neuropterida: Raphidioptera). ZooKeys 204, $1-40$.

Peris, D., Davis, S.R., Engel, M.S., Delclòs, X., 2014. An evolutionary history embedded in amber: reflection of the Mesozoic shift in weevil-dominated (Coleoptera: Curculionoidea) faunas. Zoological Journal of the Linnean Society 171, 534-553.

Pike, E.M., 1995. Amber taphonomy and the Grassy Lake, Alberta, amber fauna. Ph. D. dissertation, University of Calgary. 264 pp.

Prokop, J., Krzeminski, W., Krzeminska, E., Hörnschemeyer, T., Ilger, J.-M., Brauckmann, C., Grandcolas, P., Nel, A., 2014. Late Palaeozoic Paoliida is the sister group of Dictyoptera (Insecta: Neoptera). Journal of Systematic Palaeontology, 12, 601-622.

Querol, X., Salas, R., Pardo, G., Ardevol, L., 1992. Albian coal-bearing deposits of the Iberian Range in northeastern Spain, in: P.J. McCabe, J.T. Parrisch (Eds), Controls on the distribution and quality of Cretaceous coals. Geological Society of America Special Paper 267, pp. 193-208.

Rasnitsyn, A.P, Ross, A.J., 2000. A preliminary list of arthropod families present in the Burmese amber collection at The Natural History Museum, London. Bulletin of the Natural History Museum, Geology Series 56, 21-24.

Rodríguez-López, J.P., Meléndez, N., Soria, A.R., de Boer, P.L., 2009. Reinterpretación estratigráfica y sedimentológica de las formaciones Escucha y Utrillas de la Cordillera Ibérica. Revista de la Sociedad Geológica de España 22, 163-219.

Ross, A.J., 2015. Insects in Burmese amber. Entomologentagung 02, Frankfurt/M. Programm und Abstracts. p. 72.

Ross, A.J., York, P.V., 2004. The Lower Cretaceous (Albian) arthropod fauna of Burmese amber, Myanmar: Foreword. Journal of Systematic Palaeontology 2, 95100.

Ross, A.J., Mellish, C., York, P., Crighton, B., 2010. Burmese Amber, in: D. Penney (Ed.), Biodiversity of fossils in amber from the major world deposits. Siri Scientific Press, Manchester, pp. 208-235.

Rust, J., Singh, H., Rana, R.S., McCann, T., Singh, L., Anderson, K., Sarkar, N., Nascimbene, P.C., Stebner, F., Thomas, J.C., Solórzano Kraemer, M., Williams, Ch. J., Engel, M.S., Sahni, A., Grimaldi, D., 2010. Biogeographic and evolutionary 
implications of a diverse paleobiota in amber from the early Eocene of India. PNAS Early Edition, 1-6.

Roy, R., 1999. Morphology and taxonomy, in: F.R. Prete, H. Wells, P.H. Wells, L.E. Hurd (Eds.), The Praying Mantids. The Johns Hopkins University Press, London, pp. $19-40$.

Saupe, E.E., Pérez-de la Fuente, R., Selden, P.A., Soriano, C., Delclòs, X., Tafforeau, P., 2012. New Orchestina (Simon, 1882) (Araneae: Oonopidae) from Cretaceous ambers of Spain and France: First spiders described using phase-contrast X-ray synchrotron microtomography. Palaeontology 55, 127-143.

Shi, G., Grimaldi, D.A., Harlowb, G.E., Wang, J., Wang, J., Yang, M., Lei, W., Li, Q., $\mathrm{Li}, \mathrm{X} ., 2012$. Age constraint on Burmese amber based on $\mathrm{UePb}$ dating of zircons. Cretaceous Research 37, 155-163.

Shih-Wei, L., 2014. New Lower Cretaceous basal mantodean (Insecta) from the Crato Formation (NE Brazil). Geologica Carpathica 65, 285-292.

Svenson, G.J., Whiting, M.F., 2004. Phylogeny of Mantodea based on molecular data: Evolution of a charismatic predator. Systematic Entomology 29, 359-370.

Svenson, G.J., Whiting, M.F., 2007. Tracing the origins of the praying mantises (Dictyoptera: Mantodea): The emergence of modern Gondwanaland mantises and their subsequent ecomorphic convergences. Entomological Society of America Annual Meeting, 0279.

Svenson, G.J., Whiting, M.F., 2009. Reconstructing the origins of praying mantises (Dictyoptera, Mantodea): The roles of Gondwanan vicariance and morphological convergence. Cladistics 25, 468-514.

Thorne, B.L., Carpenter, J.M., 1992. Phylogeny of the Dictyoptera. Systematic Entomology 17, 253-268.

Villanueva-Amadoz, U., Pons, D., Diez, J.B., Ferrer, J., Sender, L.M., 2010. Angiosperm pollen grains of San Just site (Escucha Formation) from the Albian of the Iberian Range (north-eastern Spain). Review of Palaeobotany and Palynology $162,362-381$.

Vršanský, P., 2002a. Origin and the early evolution of mantises. AMBA Projekty 6, 1$16 \mathrm{p}$.

Vršanský, P., 2002b. Jantarimantis nom. nov. and Jantarimantidae nom. nov., new replacement names for the genus Archimantis Vršanský, 2002, and the family Archimantidae Vršanský, 2002 (Insecta, Mantodea). AMBA projekty 6, 1.

Vršanský, P., 2005. Lower Cretaceous cockroaches and mantids (Insecta: Blattaria, Mantodea) from the Sharin-Gol in Mongolia. Entomological Problems 35, 163-167.

Vršanský, P., 2012. Enigmatic Late Permian cockroaches from Isady, Russia (Blattida: Mutoviidae fam. n.). Zootaxa 3247, 19-31.

Vršanský, P., Bechly, G., 2015. New predatory cockroaches (Insecta: Blattaria: Manipulatoridae fam. n.) from the Upper Cretaceous Myanmar amber. Geologica Carpathica 66 (2), 133-138.

Ware, J.L., Grimaldi, D.A., Engel, M.S., 2010. The effects of fossil placement and calibration on divergence times and rates: An example from the termites (Insecta: Isoptera). Arthropod Structure and Development 39, 204-219.

Weitschat, W., Wichard, W., 2002. Atlas of Plants and Animals in Baltic Amber. Verlag Dr. Friedrich Pfeil, 256 pp.

Wieland, F., 2010. The phylogenetic system of Mantodea (Insecta: Dictyoptera). Dissertation zur Erlangung des Doktorgrades der MathematischNaturwissenschaftlichen Fakultäten der Georg-August-Universität zu Göttingen, pp. $303+$ appendix XXIX. 
Wieland, F., 2013. The phylogenetic system of Mantodea (Insecta: Dictyoptera). Species, Phylogeny and Evolution 3, 3-222.

Wunderlich, J., 2015. Mesozoic spiders (Araneae): Ancient spider faunas and spider evolution, papers on fossil and extant Araneae as well as fossil Amblypygi, Ricinulei, Scorpiones and Uropygi. Beiträge zur Araneologie 9, 1-512.

Zherikhin, V.V., 2002. Order Mantida Latreille, 1802. The mantises (= Mantodea Burmeister, 1838), in: A.P. Rasnitsyn, D.L.J. Quicke (Eds.), History of Insects. Kluwer Academic Publishers, Dordrecht, pp. 273-276.

Zompro, O., 2005. Inter- and intra-ordinal relationships of the Mantophasmatodea, with comments on the phylogeny of polyneopteran orders (Insecta: Polyneoptera). Mitteilungen aus dem Geologisch-Paläontologischen Institut der Universität Hamburg 89, 85-116. 


\section{Table 1. Known Fossil Mantodea}

Family incertae sedis

\section{Ambermantis}

- Ambermantis wozniaki Grimaldi, 2003; Turonian from New Jersey. Grimaldi (2003) erected the family Ambermantidae to include this species, but see Wieland (2013).

\section{Amorphoscelites}

- Amorphoscelites sharovi Gratshev and Zherikhin, 1993; Valanginian-Hauterivian from Siberia. Fragmentary foreleg; originally placed in Amorphoscelidae: uncertain familial placement sensu Grimaldi (2003).

\section{Aragonimantis}

- Aragonimantis aenigma gen. and sp. nov.; middle-upper Albian from San Just (Spain).

Burmantis (=Gryllomantis Gorochov, 2006)

- Burmantis asiatica Grimaldi, 2003; upper Albian-lower Cenomanian from Myanmar.

- B. lebanensis Grimaldi, 2003; Aptian from Bcharreh Mountain and AlRihan/Jezzine (Lebanon).

$=$ Gryllomantis lebanensis (Grimaldi, 2003) sensu Gorochov (2006) in Gryllomantidae sensu Gorochov (2006).

- B. zherikhini sp. nov.; upper Albian-lower Cenomanian from Myanmar.

\section{Chaeteessites}

- Chaeteessites minutissimus Gratshev and Zherikhin, 1993; Santonian from Taymyr Peninsula (Siberia) - Uncertain familial placement sensu Grimaldi (2003).

Cretophotina [originally included in Chaeteessidae but uncertain familial placement sensu Grimaldi (2003)]

- Cretophotina mongolica Gratshev and Zherikhin, 1993; Barremian-Aptian from Mongolia.

- C. santanensis Shih-Wei, 2014; Aptian from Santana do Carirí, Brazil.

- C. serotina Gratshev and Zherikhin, 1993; Turonian from Kazakhastan.

- C. tristriata Gratshev and Zherikhin, 1993; Valanginian-Hauterivian from Siberia.

- C. selenginesis Vršanský, 2002; Lower Cretaceous from Sharin-Gol (Mongolia).

- Cretophotina sp.; Barremian from Las Hoyas (Spain). In Vršanský (2002).

- Cretophotina sp.; Berriasian-Valanginian from Sharin-Gol (Mongolia). In Vršanský (2005).

\section{Electromantis}

- Electromantis sukatshevae Gratshev and Zherikhin, 1993; Santonian from Taymyr Peninsula (Siberia) - Originally placed in Cretomantidae: uncertain familial placement sensu Grimaldi (2003).

Jersimantis

- Jersimantis luzzii Grimaldi, 1997; Turonian from New Jersey. 
- J. burmiticus Grimaldi, 2003; upper Albian-lower Cenomanian from Myanmar = Burmantis burmitica (Grimaldi, 2003) sensu Gorochov (2006).

Kazakhophotina

- Kazakhophotina corrupta Gratshev and Zherikhin, 1993; Turonian from Kazakhstan. Fragment of the wing. Originally included in Chaeteessidae: uncertain familial placement sensu Grimaldi (2003).

\section{Vitimophotina}

- Vitimophotina corrugata Gratshev and Zherikhin, 1993; Valanginian-Hauterivian from Siberia. Fragmentary wing. Originally included in Chaeteessidae: uncertain familial placement sensu Grimaldi (2003).

Genus unknown

- Unclassified Mantis. Santonian from Kuji, Iwate Prefecture, NE Japan. See http://news.nationalgeographic.com/news/2008/04/080425-amber-mantis.html (2015 feb.).

Baissomantidae $\dagger$

- Baissomantis maculata Gratshev and Zherikhin, 1993; Valanginian-Hauterivian from Siberia.

- B. picta Gratshev and Zherikhin, 1993; Valanginian-Hauterivian from Siberia.

Cretomantidae $\dagger$

- Cretomantis larvalis Gratshev and Zherikhin, 1993; Valanginian-Hauterivian from Siberia.

Santanmantidae $\dagger$

- Santanmantis axelrodi Grimaldi, 2003; Aptian from Santana do Cariri, in Brazil. See Hörnig et al. (2013).

Chaeteessidae (=Archephemeridae)

- Arvernineura insignis Piton, 1940; Paleocene from Menat (France). See Nel and Roy (1996).

- Lithophotina costalis Cockerell, 1914; Eocene from Colorado. In Meyer (2003).

- Lithophotina floccosa Cockerell, 1908; Eocene from Colorado. In Meyer (2003).

- Megaphotina sichotensis Gratshev and Zherikhin, 1993; Oligocene from SikhoteAlin.

- Chaeteessa sp.; Aptian from Santana do Cariri, in Brazil. In Shih-Wei (2011), but see also Shih-Wei (2014).

- Chaeteessa sp.; Miocene from the Dominican Republic. In Grimaldi (2003).

- Chaeteessidae sp.; Eocene from Baltic amber. In Erhmann (1999).

- Chaeteessidae sp.; Oligocene from Germany. In Erhmann (1999).

- Chaeteessidae sp.; Campanian from Canada. In Erhmann (1999).

- Chaeteessidae sp.; Eocene from India. In Rust et al. (2010).

Possibly in Chaeteessidae

- Archaeophlebia enigmatica Piton, 1940; Paleocene from Menat (France). See Nel and Roy (1996). 
Mantidae

- Eobruneria tessellata Cockerell, 1913; Eocene from Colorado. In Meyer (2003).

- Mantis religiosa (Linné, 1758); Pliocene from Willershausen (Germany). In Beier (1967).

- Mantidae sp.; Miocene from the Dominican Republic. In Grimaldi (2003).

- Mantidae sp.; Oligocene from Germany. In Ehrmann (1999).

- Mantidae sp.; Eocene from Baltic amber. In Grimaldi (2003).

- Prochaeradodis enigmaticus Piton, 1940; Paleocene of Menat (France). See Nel and Roy (1996).

Mantoididae

- Mantoida matthiasglinki Zompro, 2005; Eocene from Baltic amber.

- Mantoida sp.; Miocene from the Dominican Republic. In Grimaldi (2003).

- Mantoididae sp.; Eocene from Baltic amber. In Weitschat and Wichard (2002). Excluded from this family by Wieland (2013).

Liturgusidae

- Liturgusidae sp.; Eocene from Baltic amber. In Erhmann (1999).

- Liturgusidae sp.; Miocene from the Dominican Republic. In Erhmann (1999).

Tarachodidae

- Tarachodidae sp.; Miocene from the Dominican Republic. In Erhmann (1999).

Vatidae

- Vatidae sp.; Miocene from the Dominican Republic. In Erhmann (1999).

\section{Excluded from Mantodea}

Juramantidae $\dagger$

- Juramantis initialis Vršanský, 2002; Upper Jurassic from Shar-Teg in Mongolia. Not considered as a Mantodea by Grimaldi (2003) because of the absence of characters of Mantodea.

Jantarimantidae $\dagger$ (= Archimantidae Vršanský, 2002)

- Jantarimantis zherikhini (Vršanský, 2002) (= Archimantis zherikhini Vršanský, 2002 [Archimantis praeocc. Saussure, 1869]). Turonian from New Jersey. According to Grimaldi (2003) the holotype of this species is a roach belonging to the family Umenocoleidae (now Ponopterixidae). A second specimen studied by Vršanský (but not considered as a paratype) was later considered a paratype of Ambermantis wozniaki Grimaldi, 2003. 
Table 2. Reduced matrix of taxa and characters modified from that proposed by Grimaldi (2003) and Wieland (2013), with the addition of Aragonimantis aenigma gen. et sp. nov., and Burmantis zherikhini sp. nov. (in Burmantis spp.); (†) fossil record.

\begin{tabular}{|c|c|c|c|c|c|c|c|c|}
\hline & 1 & 2 & 3 & 4 & 5 & 6 & 7 & 8 \\
\hline Baissomantis ssp. $^{(\dagger)}$ & $?$ & $?$ & $?$ & $?$ & $?$ & $?$ & $?$ & $?$ \\
\hline Jersimantis ssp. ${ }^{(\dagger)}$ & 1 & 1 & 0 & 0 & 1 & 0 & 1 & 0 \\
\hline Chaeteessites minutissimus ${ }^{(\dagger)}$ & 1 & 1 & 0 & 0 & 1 & $?$ & $?$ & $?$ \\
\hline Burmantis ssp. ${ }^{(\dagger)}$ & 1 & 1 & 0 & 0 & 1 & 0 & 1 & 1 \\
\hline Aragonimantis aenigma $^{(\dagger)}$ & 1 & 1 & 0 & 0 & 1 & $?$ & 1 & 1 \\
\hline Electromantis sukatshevae ${ }^{(\dagger)}$ & 1 & 1 & 0 & 0 & 0 & $?$ & 0 & 0 \\
\hline Cretomantis larvalis ${ }^{(\dagger)}$ & 1 & 0 & 0 & 0 & 0 & 0 & 0 & 0 \\
\hline Santanmantis axelrodi ${ }^{(\dagger)}$ & 1 & 0 & 0 & 0 & 0 & 0 & 0 & 0 \\
\hline Cretophotina spp. ${ }^{(\dagger)}$ & $?$ & $?$ & $?$ & $?$ & $?$ & $?$ & $?$ & $?$ \\
\hline Ambermantis wozniaki $^{(\dagger)}$ & 1 & 1 & 0 & 0 & 0 & 1 & 0 & 0 \\
\hline Chaeteessa spp. & 1 & 1 & 1 & 1 & 0 & 1 & 0 & 0 \\
\hline Mantoida spp. & 1 & 1 & 1 & 1 & 0 & 0 & 0 & 0 \\
\hline Metallyticus spp. & 1 & 1 & 1 & 1 & 0 & 0 & 0 & 0 \\
\hline Amorphoscelis spp. & 1 & 1 & 1 & 1 & 0 & 0 & 0 & 0 \\
\hline Remaining Mantodea & 1 & 1 & 1 & 1 & 0 & 0 & 0 & 0 \\
\hline
\end{tabular}




\section{Figure Captions}

Fig. 1. Palaeogeographic map showing the provenance of the studied specimens (map after Blackey, 2011). In the text there are detailed information from geology of the outcrops, and the fossil record associated to a new species.

Fig. 2. Aragonimantis aenigma gen. and sp. nov., holotype: SJ-10-17, in ventral habitus and dorsal view of head and anterior margin of pronotum.

Fig. 3. Aragonimantis aenigma gen. and sp. nov., holotype: SJ-10-17. 1) habitus, 2) maxillary palp, 3) left raptorial foreleg, 4) distal part of protibia and its distal spines, 5) detail of protibia and base of tarsus, 6) arolium and distal claws of foreleg pretarsus, 7) midleg surface, 8) distal spine of mesotibia. Scale bars: 1 and 3: $1.5 \mathrm{~mm} ; 5: 1 \mathrm{~mm} ; 2,4$, 6-8: $200 \mu \mathrm{m}$.

Fig. 4. Reconstruction of forelegs of some Cretaceous mantises. 1) Burmantis sp. (after Grimaldi, 2003, and our observations), 2) Aragonimantis aenigma gen. and sp. nov. (this paper), 3) Jersimantis sp. (after Grimaldi, 2003), 4) Cretomantis larvalis (after Gratshev and Zherikhin, 1993), 5) Chaeteessites minutissimus (after Grimaldi, 2003, and our observations). Not all to the same scale.

Fig. 5. Burmantis lebanensis Grimaldi, specimen RIH-1E dorsal habitus, showing complete preserved chaetotaxy and body colour pattern, and lateral habitus less detailed.

Fig. 6. Burmantis lebanensis Grimaldi, specimen RIH-1E. 1) head and raptorial left foreleg in frontal view, 2) same in ventral view, 3) right profemur in externo-lateral view (five arrows indicate five stout, short spines of ventromesal row), 4) genitalia in 
lateral view showing cercal colour pattern (styli have been highlighted), 5) thoracic nota in dorsal view, showing colour pattern, complete chaetotaxy, and two details of scalelike microsculpture. Scale bars: 1-2: $1 \mathrm{~mm}, 3-7: 200 \mu \mathrm{m}$.

Fig. 7. Burmantis lebanensis Grimaldi, specimen RIH-1E. 1) habitus in dorsal view, 2) habitus in ventral view, 3) protibia showing distribution of spines, 4) right profemur in externo-lateral view showing the anteroventral row of spines and some stiff setae, 5) same area at different focal plane and showing spines on posteroventral profemoral edge, 6) lateral view of genitalia depicting a stylus in plane of focus, 7) ventral view of cercus.

Fig. 8. Burmantis zherikhini sp. nov., holotype NMS G.2010.20.8. 1) head and anterior part of thorax in lateral view, 2) pronotum in lateral view showing colour pattern, chaetotaxy, and a detail of its scale-like microsculpture, 3) raptorial foreleg most likely showing a brush (see arrow and area magnified) comprised of minute scales (this structure was not observed with confidence) and detail of first posteroventral profemoral spine.

Fig. 9. Burmantis zherikhini sp. nov., holotype NMS G.2010.20.8 (photographs by Bill Crighton). 1) habitus, 2) maxillary palp, 3) first posteroventral profemoral spine, 4) detail of same spine with higher magnification. Scale bars: 1: $1 \mathrm{~mm}, 2-4: 200 \mu \mathrm{m}$.

Fig. 10. 50\% majority rule consensus cladogram of studied Cretaceous mantis genera. $(\dagger)$ fossil genera. 


\section{Tables}

Table 1. Known Fossil Mantodea.

Table 2. Reduced matrix of taxa and characters modified from that proposed by Grimaldi (2003) and Wieland (2013), with the addition of Aragonimantis aenigma gen. et sp. nov., and Burmantis zherikhini sp. nov. (in Burmantis spp.). 


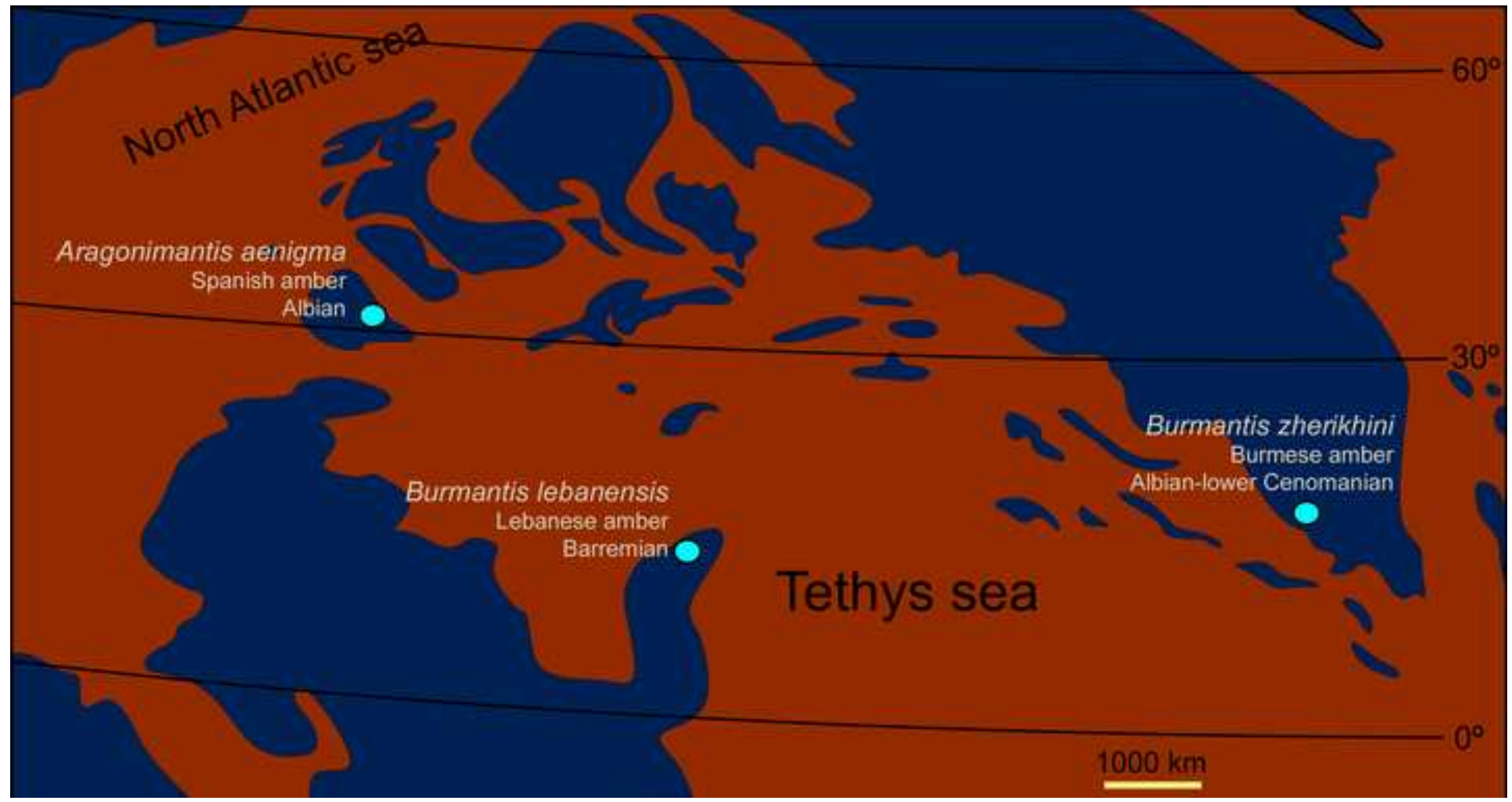




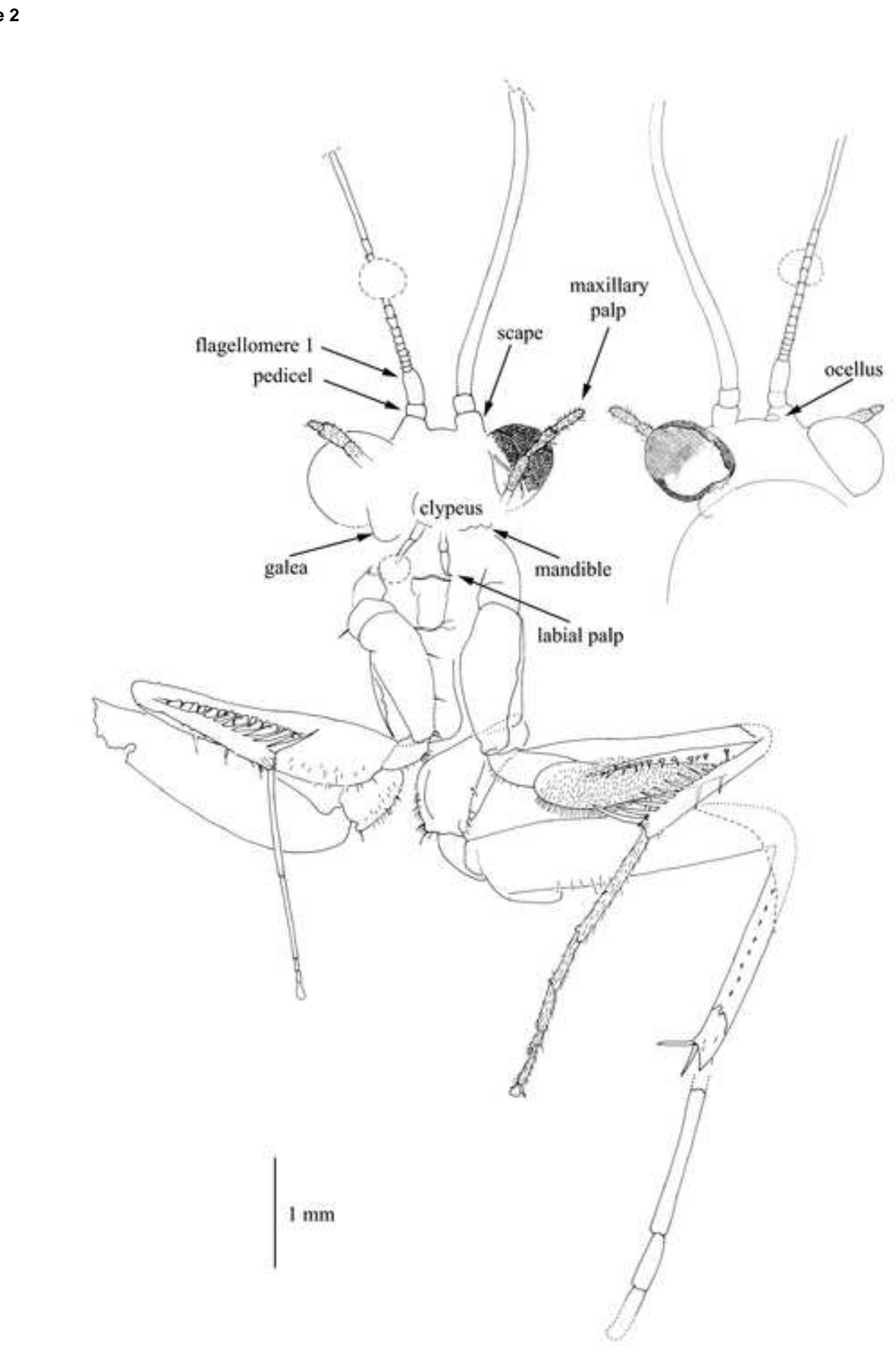

Figure 2

.




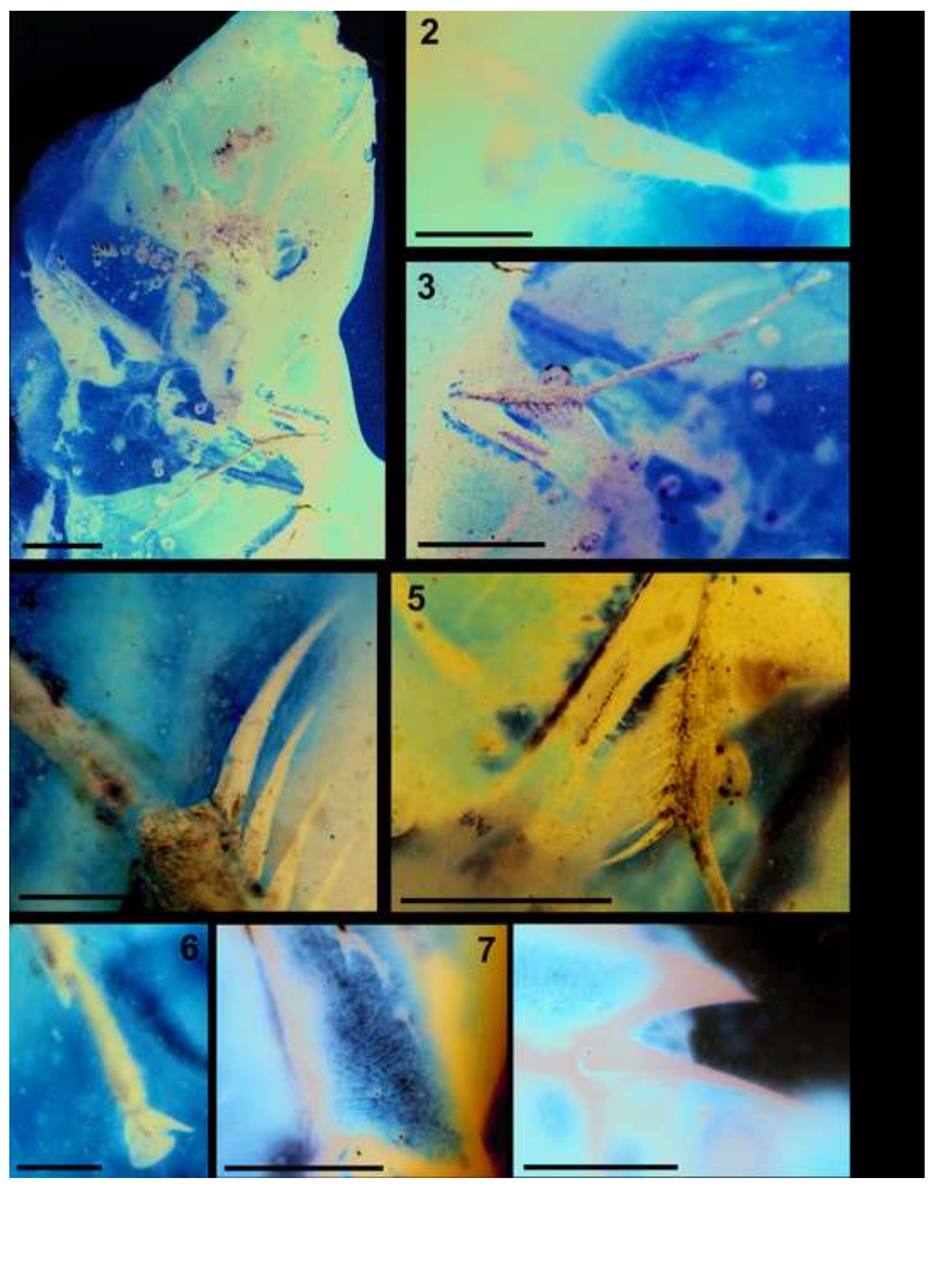

Figure 3

\section{Figure 3}

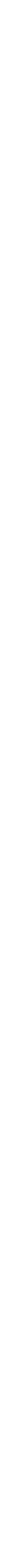

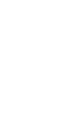

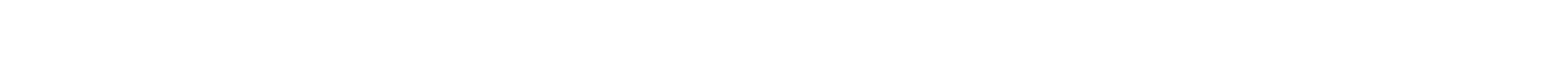

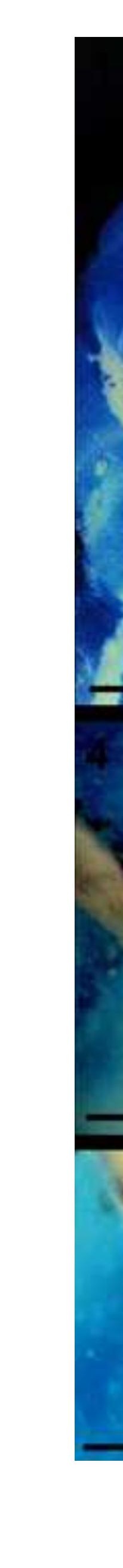

of




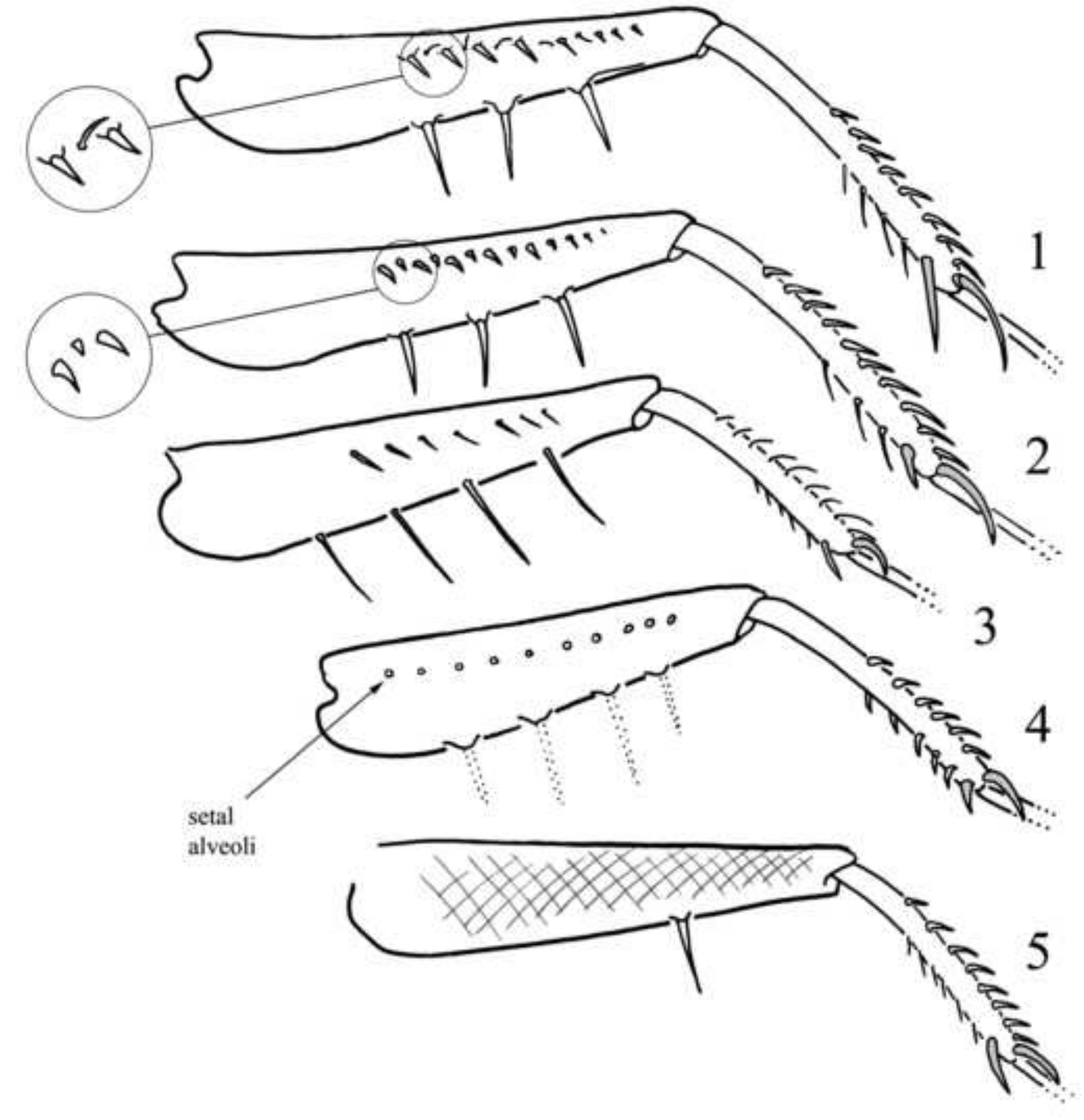

Figure 4 


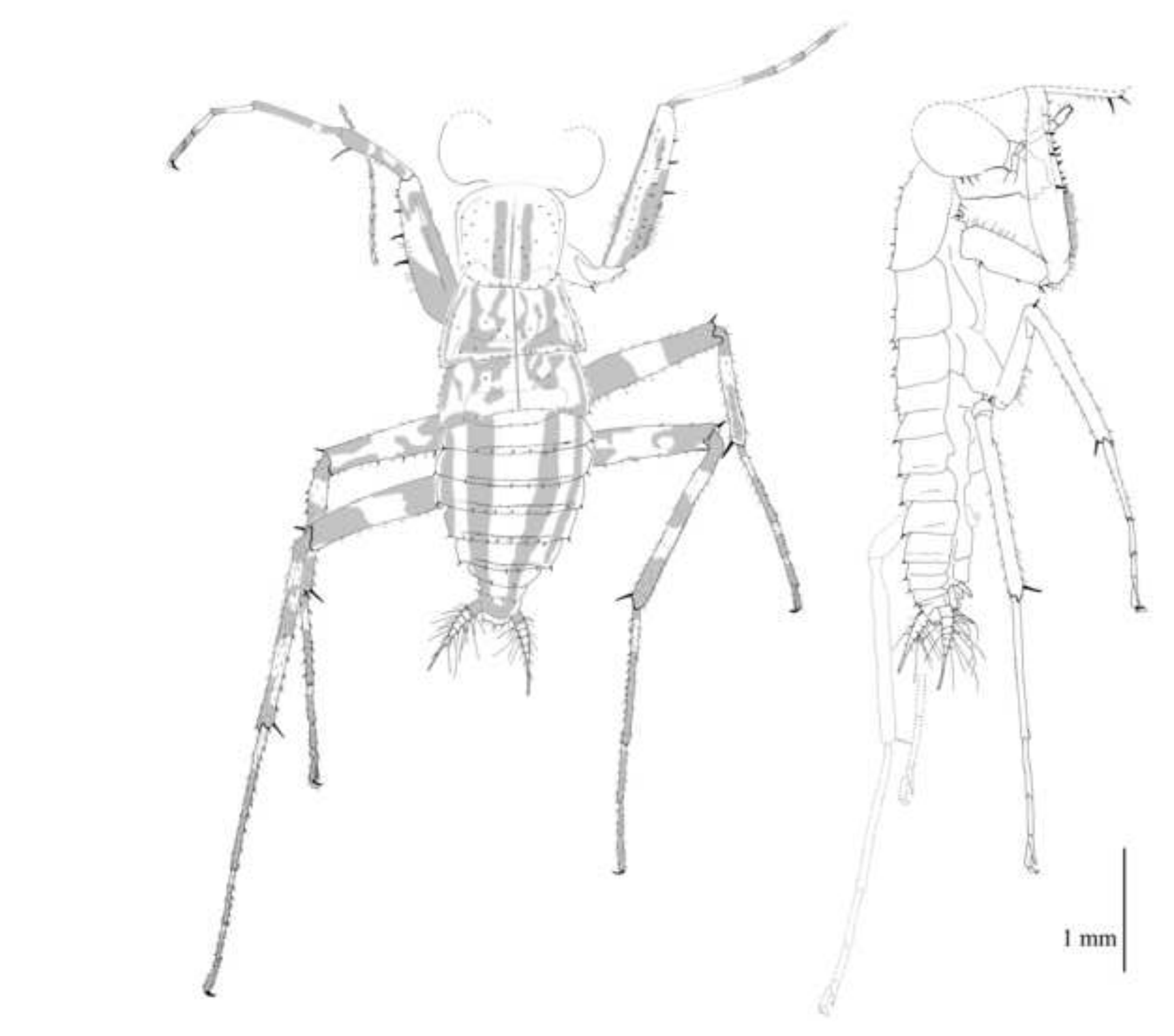

. 

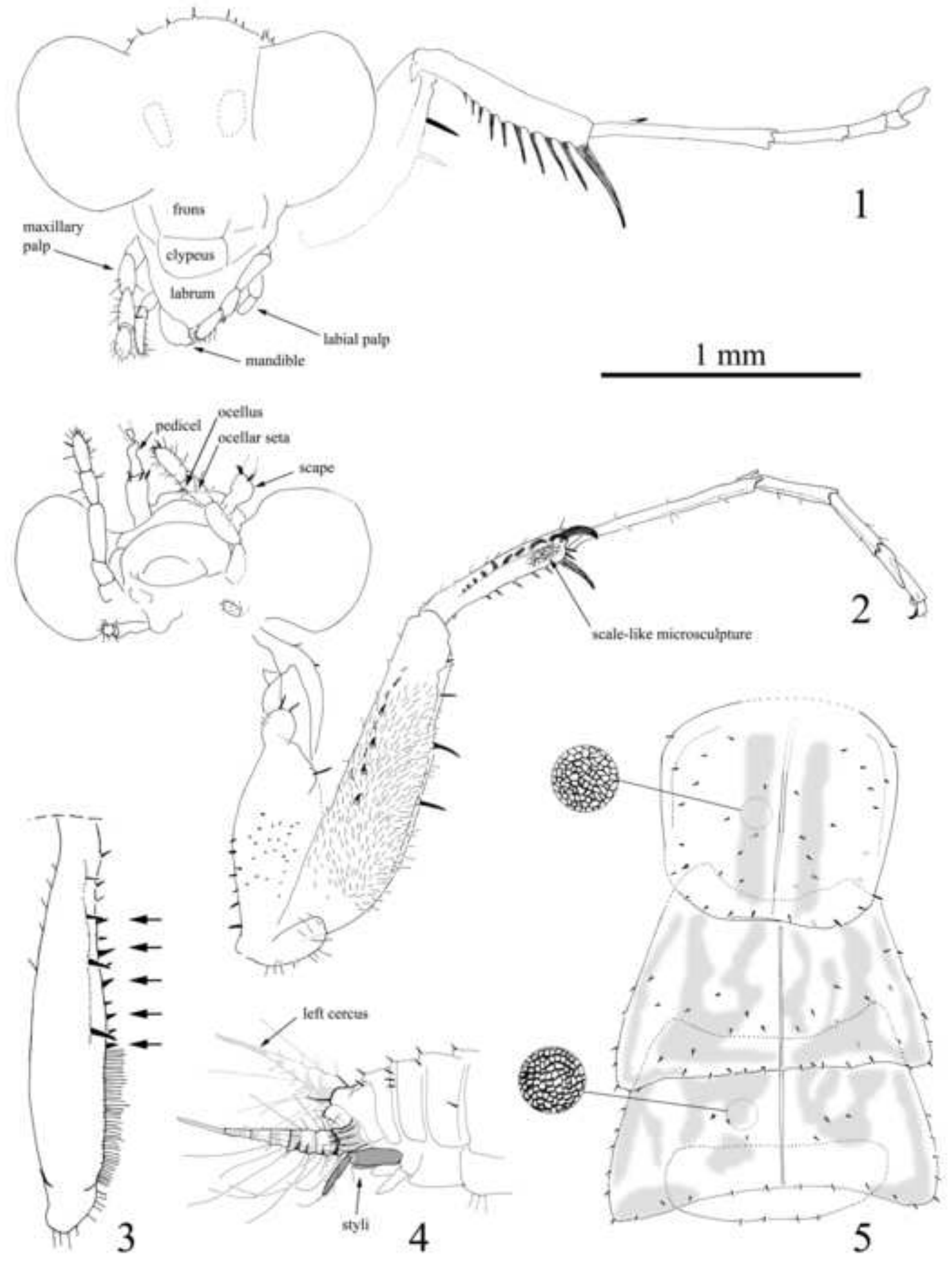

Figure 6 


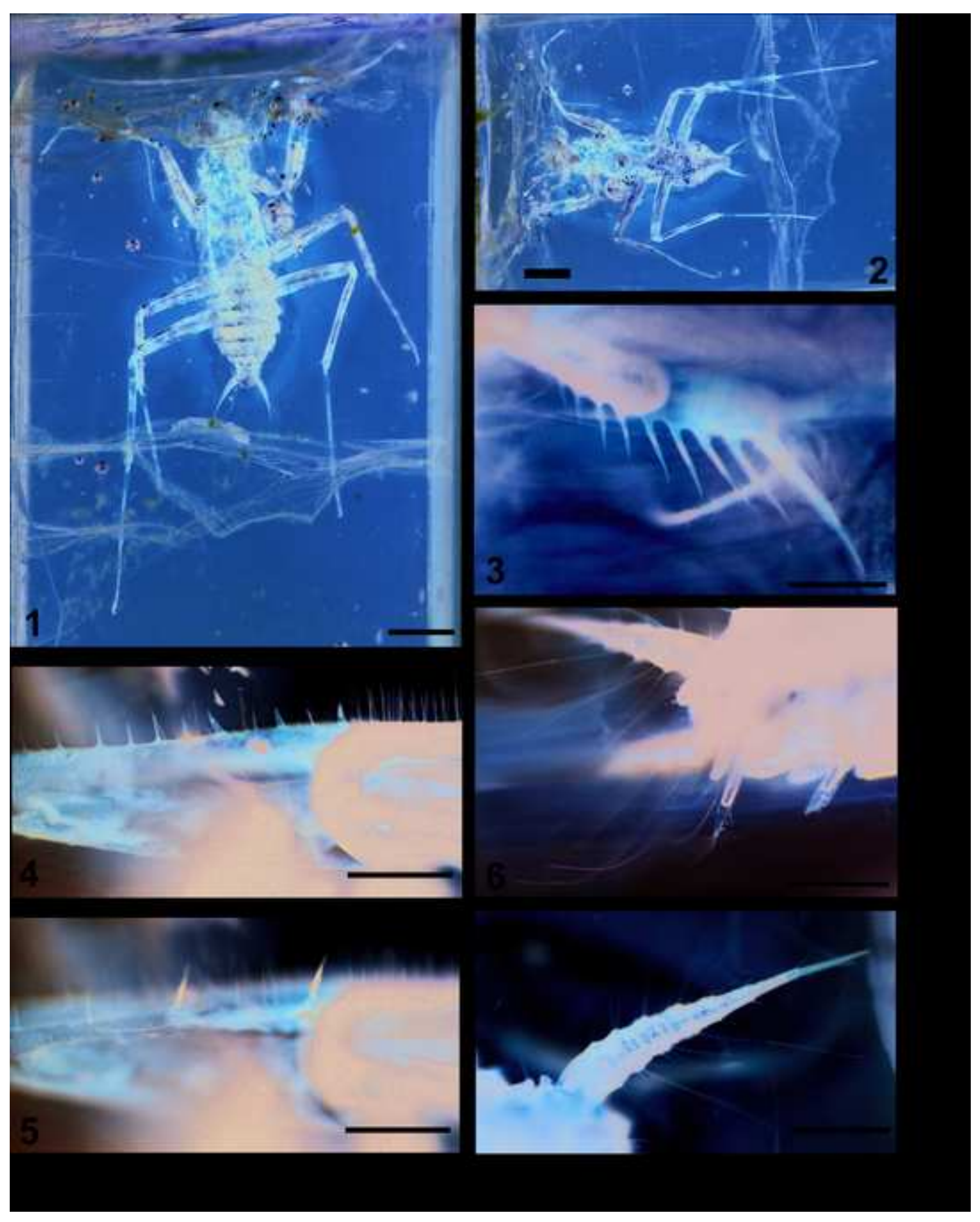

Figure 7

(

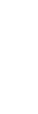

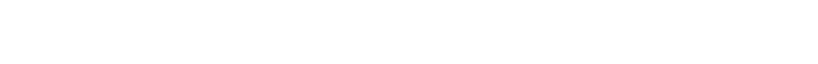
-

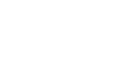$$
\text { 然 }
$$ 


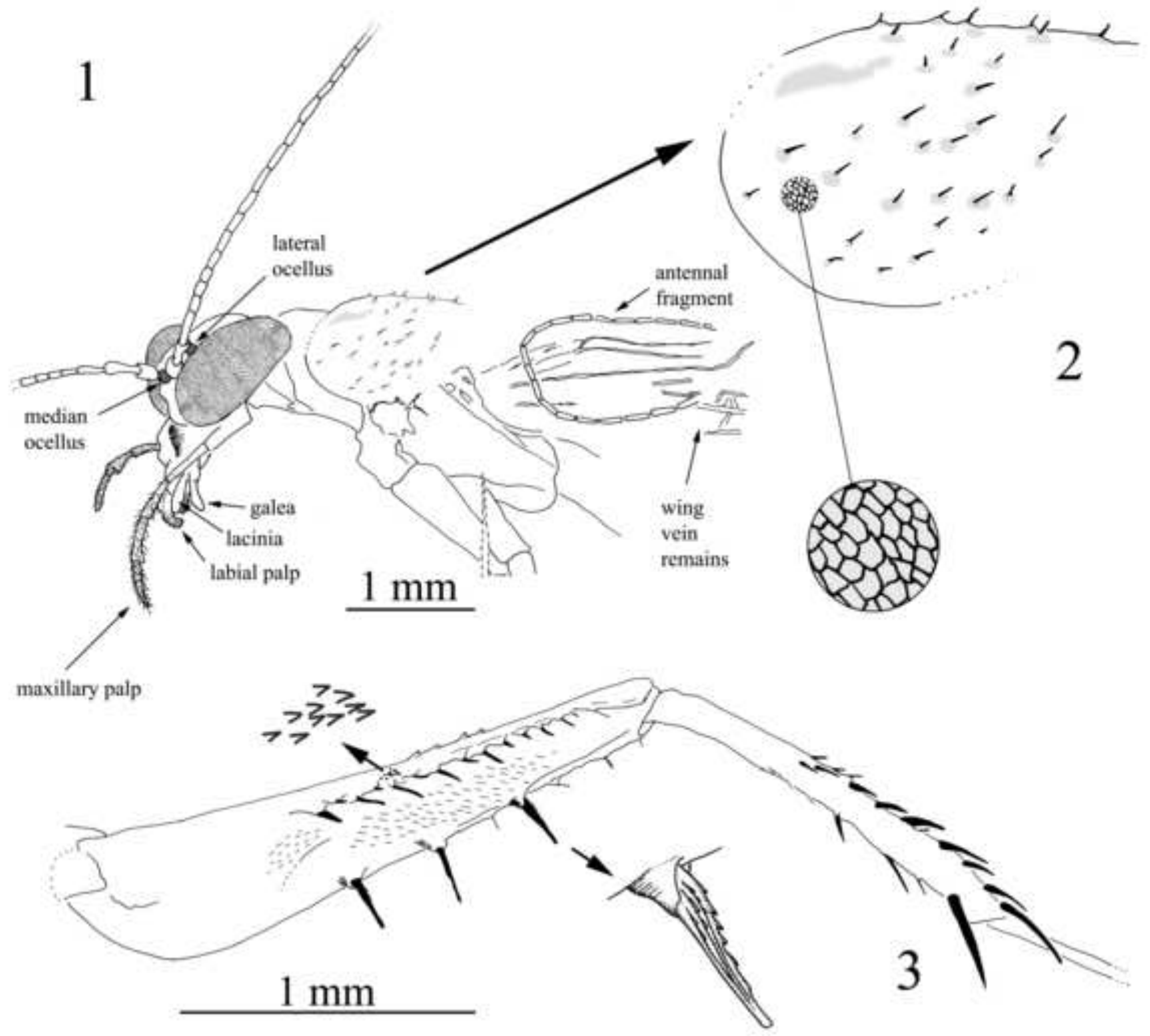


Figure here to download high resolution image
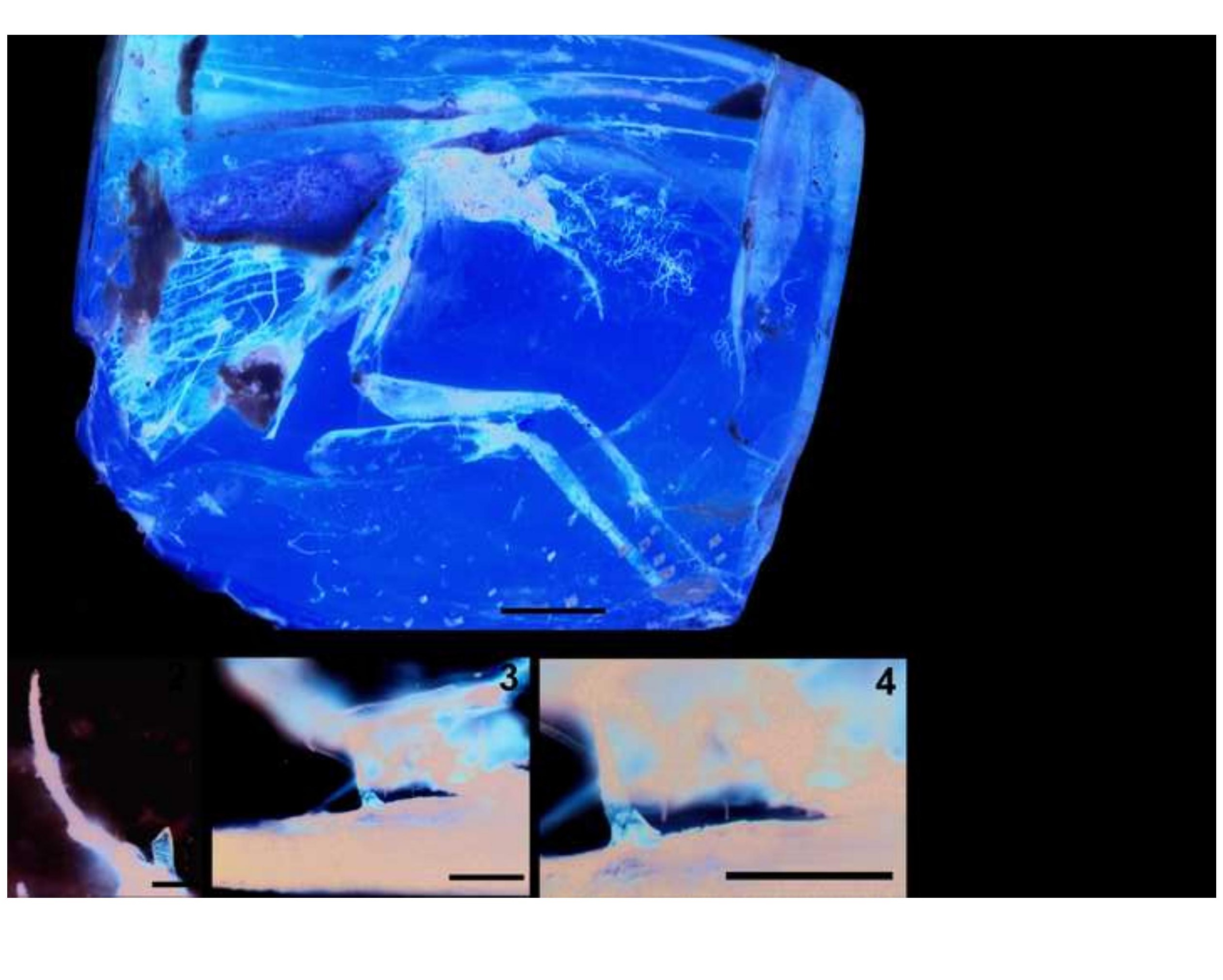


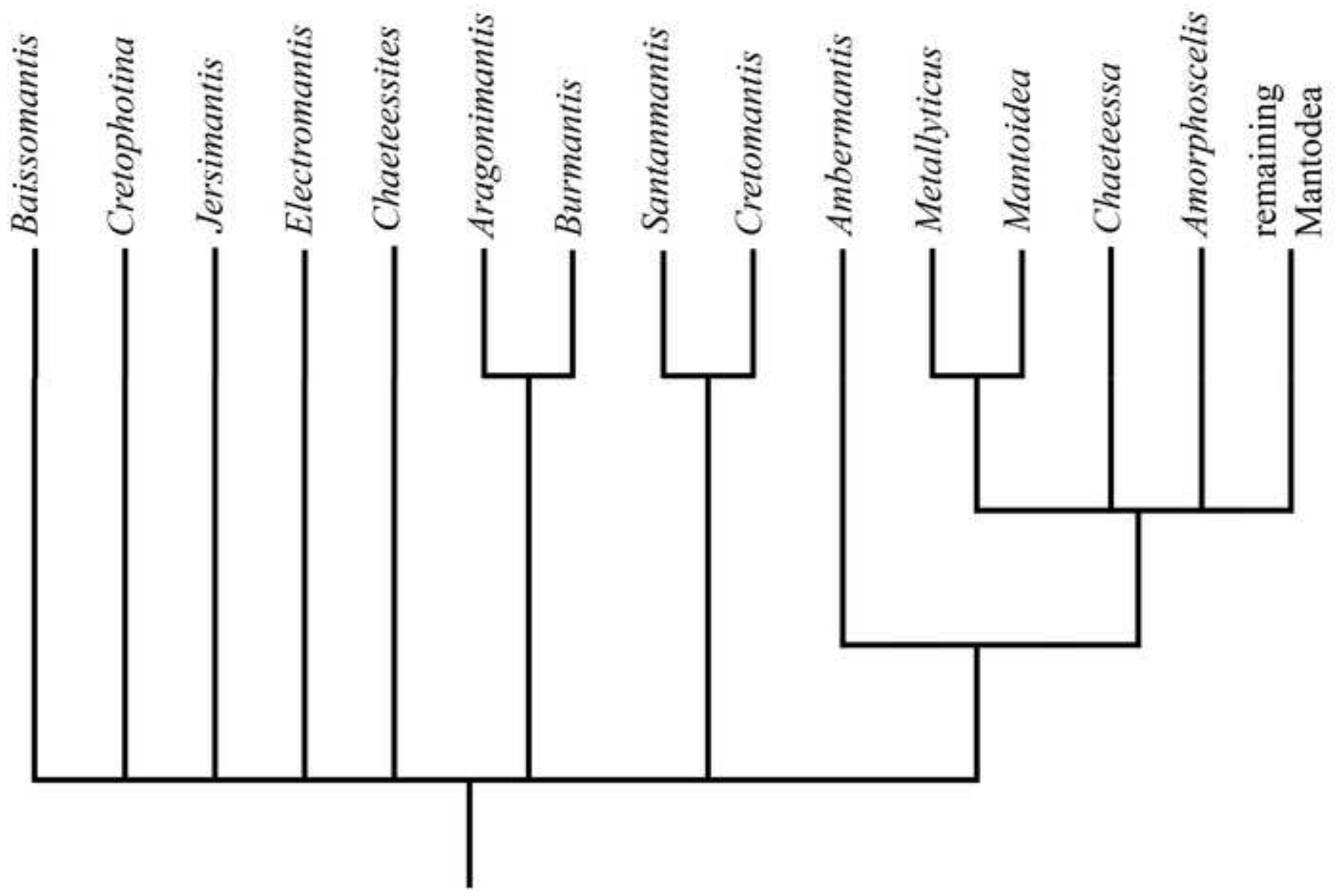




\section{Table 1. Known Fossil Mantodea}

Family incertae sedis

\section{Ambermantis}

- Ambermantis wozniaki Grimaldi, 2003; Turonian from New Jersey. Grimaldi (2003) erected the family Ambermantidae to include this species, but see Wieland (2013).

\section{Amorphoscelites}

- Amorphoscelites sharovi Gratshev and Zherikhin, 1993; Valanginian-Hauterivian from Siberia. Fragmentary foreleg; originally placed in Amorphoscelidae: uncertain familial placement sensu Grimaldi (2003).

\section{Aragonimantis}

- Aragonimantis aenigma gen. and sp. nov.; middle-upper Albian from San Just (Spain).

Burmantis (=Gryllomantis Gorochov, 2006)

- Burmantis asiatica Grimaldi, 2003; upper Albian-lower Cenomanian from Myanmar.

- B. lebanensis Grimaldi, 2003; Aptian from Bcharreh Mountain and AlRihan/Jezzine (Lebanon).

= Gryllomantis lebanensis (Grimaldi, 2003) sensu Gorochov (2006) in Gryllomantidae sensu Gorochov (2006).

- B. zherikhini sp. nov.; upper Albian-lower Cenomanian from Myanmar.

\section{Chaeteessites}

- Chaeteessites minutissimus Gratshev and Zherikhin, 1993; Santonian from Taymyr Peninsula (Siberia) - Uncertain familial placement sensu Grimaldi (2003).

Cretophotina [originally included in Chaeteessidae but uncertain familial placement sensu Grimaldi (2003)]

- Cretophotina mongolica Gratshev and Zherikhin, 1993; Barremian-Aptian from Mongolia.

- C. santanensis Shih-Wei, 2014; Aptian from Santana do Carirí, Brazil.

- C. serotina Gratshev and Zherikhin, 1993; Turonian from Kazakhastan.

- C. tristriata Gratshev and Zherikhin, 1993; Valanginian-Hauterivian from Siberia.

- C. selenginesis Vršanský, 2002; Early Cretaceous from Sharin-Gol (Mongolia).

- Cretophotina sp.; Barremian from Las Hoyas (Spain). In Vršanský (2002).

- Cretophotina sp.; Berriasian-Valanginian from Sharin-Gol (Mongolia). In Vršanský (2005).

\section{Electromantis}

- Electromantis sukatshevae Gratshev and Zherikhin, 1993; Santonian from Taymyr Peninsula (Siberia) - Originally placed in Cretomantidae: uncertain familial placement sensu Grimaldi (2003).

\section{Jersimantis}

- Jersimantis luzzii Grimaldi, 1997; Turonian from New Jersey. 
- J. burmiticus Grimaldi, 2003; upper Albian-lower Cenomanian from Myanmar = Burmantis burmitica (Grimaldi, 2003) sensu Gorochov (2006).

Kazakhophotina

- Kazakhophotina corrupta Gratshev and Zherikhin, 1993; Turonian from Kazakhstan. Fragment of the wing. Originally included in Chaeteessidae: uncertain familial placement sensu Grimaldi (2003).

\section{Vitimophotina}

- Vitimophotina corrugata Gratshev and Zherikhin, 1993; Valanginian-Hauterivian from Siberia. Fragmentary wing. Originally included in Chaeteessidae: uncertain familial placement sensu Grimaldi (2003).

Genus unknown

- Unclassified Mantis. Santonian from Kuji, Iwate Prefecture, NE Japan. See http://news.nationalgeographic.com/news/2008/04/080425-amber-mantis.html (2015 feb.).

Baissomantidae $\dagger$

- Baissomantis maculata Gratshev and Zherikhin, 1993; Valanginian-Hauterivian from Siberia.

- B. picta Gratshev and Zherikhin, 1993; Valanginian-Hauterivian from Siberia.

Cretomantidae $\uparrow$

- Cretomantis larvalis Gratshev and Zherikhin, 1993; Valanginian-Hauterivian from Siberia.

Santanmantidae $\dagger$

- Santanmantis axelrodi Grimaldi, 2003; Aptian from Santana do Cariri, in Brazil. See Hörnig et al. (2013).

Chaeteessidae (=Archephemeridae)

- Arvernineura insignis Piton, 1940; Paleocene from Menat (France). See Nel and Roy (1996).

- Lithophotina costalis Cockerell, 1914; Eocene from Colorado. In Meyer (2003).

- Lithophotina floccosa Cockerell, 1908; Eocene from Colorado. In Meyer (2003).

- Megaphotina sichotensis Gratshev and Zherikhin, 1993; Oligocene from SikhoteAlin.

- Chaeteessa sp.; Aptian from Santana do Cariri, in Brazil. In Shih-Wei (2011), but see also Shih-Wei (2014).

- Chaeteessa sp.; Miocene from the Dominican Republic. In Grimaldi (2003).

- Chaeteessidae sp.; Eocene from Baltic amber. In Erhmann (1999).

- Chaeteessidae sp.; Oligocene from Germany. In Erhmann (1999).

- Chaeteessidae sp.; Campanian from Canada. In Erhmann (1999).

- Chaeteessidae sp.; Eocene from India. In Rust et al. (2010).

Possibly in Chaeteessidae

- Archaeophlebia enigmatica Piton, 1940; Paleocene from Menat (France). See Nel and Roy (1996). 
Mantidae

- Eobruneria tessellata Cockerell, 1913; Eocene from Colorado. In Meyer (2003).

- Mantis religiosa (Linné, 1758); Pliocene from Willershausen (Germany). In Beier (1967).

- Mantidae sp.; Miocene from the Dominican Republic. In Grimaldi (2003).

- Mantidae sp.; Oligocene from Germany. In Ehrmann (1999).

- Mantidae sp.; Eocene from Baltic amber. In Grimaldi (2003).

- Prochaeradodis enigmaticus Piton, 1940; Paleocene of Menat (France). See Nel and Roy (1996).

Mantoididae

- Mantoida matthiasglinki Zompro, 2005; Eocene from Baltic amber.

- Mantoida sp.; Miocene from the Dominican Republic. In Grimaldi (2003).

- Mantoididae sp.; Eocene from Baltic amber. In Weitschat and Wichard (2002). Excluded from this family by Wieland (2013).

Liturgusidae

- Liturgusidae sp.; Eocene from Baltic amber. In Erhmann (1999).

- Liturgusidae sp.; Miocene from the Dominican Republic. In Erhmann (1999).

Tarachodidae

- Tarachodidae sp.; Miocene from the Dominican Republic. In Erhmann (1999).

Vatidae

- Vatidae sp.; Miocene from the Dominican Republic. In Erhmann (1999).

\section{Excluded from Mantodea}

Juramantidae $\dagger$

- Juramantis initialis Vršanský, 2002; Upper Jurassic from Shar-Teg in Mongolia. Not considered as a Mantodea by Grimaldi (2003) because of the absence of characters of Mantodea.

Jantarimantidae $\uparrow$ (= Archimantidae Vršanský, 2002)

- Jantarimantis zherikhini (Vršanský, 2002) (= Archimantis zherikhini Vršanský, 2002 [Archimantis praeocc. Saussure, 1869]). Turonian from New Jersey. According to Grimaldi (2003) the holotype of this species is a roach belonging to the family Umenocoleidae (now Ponopterixidae). A second specimen studied by Vršanský (but not considered as a paratype) was later considered a paratype of Ambermantis wozniaki Grimaldi, 2003. 
Table 2. Reduced matrix of taxa and characters modified from that proposed by Grimaldi (2003) and Wieland (2013), with the addition of Aragonimantis aenigma gen. et sp. nov., and Burmantis zherikhini sp. nov. (in Burmantis spp.); (†) fossil record.

\begin{tabular}{|c|c|c|c|c|c|c|c|c|}
\hline & 1 & 2 & 3 & 4 & 5 & 6 & 7 & 8 \\
\hline Baissomantis ssp. ${ }^{(\dagger)}$ & $?$ & $?$ & $?$ & $?$ & $?$ & $?$ & $?$ & $?$ \\
\hline Jersimantis ssp. ${ }^{(\dagger)}$ & 1 & 1 & 0 & 0 & 1 & 0 & 1 & 0 \\
\hline Chaeteessites minutissimus ${ }^{(\dagger)}$ & 1 & 1 & 0 & 0 & 1 & ? & $?$ & $?$ \\
\hline Burmantis ssp. ${ }^{(\dagger)}$ & 1 & 1 & 0 & 0 & 1 & 0 & 1 & 1 \\
\hline Aragonimantis aenigma $^{(\dagger)}$ & 1 & 1 & 0 & 0 & 1 & $?$ & 1 & 1 \\
\hline Electromantis sukatshevae ${ }^{(\dagger)}$ & 1 & 1 & 0 & 0 & 0 & $?$ & 0 & 0 \\
\hline Cretomantis larvalis $^{(\uparrow)}$ & 1 & 0 & 0 & 0 & 0 & 0 & 0 & 0 \\
\hline Santanmantis axelrodi ${ }^{(\dagger)}$ & 1 & 0 & 0 & 0 & 0 & 0 & 0 & 0 \\
\hline Cretophotina spp. ${ }^{(\dagger)}$ & $?$ & $?$ & $?$ & $?$ & $?$ & $?$ & $?$ & $?$ \\
\hline Ambermantis wozniaki $^{(\dagger)}$ & 1 & 1 & 0 & 0 & 0 & 1 & 0 & 0 \\
\hline Chaeteessa spp. & 1 & 1 & 1 & 1 & 0 & 1 & 0 & 0 \\
\hline Mantoida spp. & 1 & 1 & 1 & 1 & 0 & 0 & 0 & 0 \\
\hline Metallyticus spp. & 1 & 1 & 1 & 1 & 0 & 0 & 0 & 0 \\
\hline Amorphoscelis spp. & 1 & 1 & 1 & 1 & 0 & 0 & 0 & 0 \\
\hline Remaining Mantodea & 1 & 1 & 1 & 1 & 0 & 0 & 0 & 0 \\
\hline
\end{tabular}


